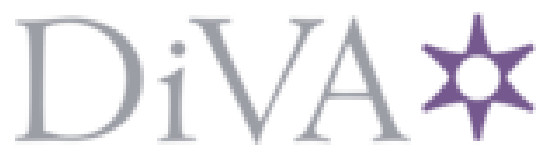

http://www.diva-portal.org

This is the published version of a paper published in Landscape History.

Citation for the original published paper (version of record):

Widgren, M. (1990)

Strip fields in an Iron-Age context: A case study from Västergötland, Sweden.

Landscape History, 12(1): 5-24

https://doi.org/10.1080/01433768.1990.10594427

Access to the published version may require subscription.

N.B. When citing this work, cite the original published paper.

Permanent link to this version:

http://urn.kb.se/resolve?urn=urn:nbn:se:su:diva-139188 


\title{
Strip fields in an Iron-Age context: a case study from Västergötland, Sweden
}

\author{
Mats Widgren
}

\section{ABSTRACT}

As part of a project on the origin of subdivided fields in Western Sweden some surprisingly old planned fields have been investigated in the southern parts of the province of Västergötland. A type of large fossilised field consisting of long strips bounded by banks of stone and earth was found while searching for partially deserted medieval sub-divided fields. The breadth of the strips varies from approximately 7 to 40 metres. To judge from the remaining evidence, the fields often covered areas of over 50 hectares. The spatial relationship between the fields and other ancient monuments points to a date in the last centuries B.C. This dating has also been confirmed by radio-carbon datings from field boundaries, indicating a use in the period 500 B.C. to A.D. 200. The layout of the strips follows geometrical principles rather than the terrain and gives the impression of deliberate planning according to some yet unknown principle. Some of the localities consist of broad strips which have functioned as frameworks within which subdivision into property and/or working plots has later been developed. This land division seems mainly to have its origin in the need to regulate the rights to land. Strips are often too broad to have been working plots and they lack any sign of traction implements. All evidence so far points to collectively organised, subdivided field systems which have many traits in common with the medieval open fields. A metrological analysis shows that the fields were planned, measured and subsequently subdivided. The finds raise principal questions concerning the origin of subdivided fields and of individual and collective rights in the landscape. Two directions for discussion emerge. One concerns the antecedent forms in the landscape and the circumstances under which these land divisions were carried out, the other concerns the principal relations between these field systems and later subdivided fields.

\section{BACKGROUND}

Research in the 1960s and 1970s in Sweden has provided us with a series of in-depth analyses of fossil agrarian landscapes dating from the centuries before Christ to the early twelfth and thirteenth centuries. The main investigations have been carried out in the Department of Human Geography at Stockholm University (Lindquist 1968, 1974, 1976; Sporrong 1971, 1985; Carlsson 1979, Widgren 1983). These research projects in different regions of central and eastern Sweden may be considered local or regional in their character, but an overall idea of the general development of the landscape has guided the investigations and general conclusions may also be drawn from them. The generalisations in these studies are concerned with the relations between the ways of restoring nutrients (the farming system), the form of settlement and how rights to land were organised.

Three distinct phases of agrarian landscapes have been identified. The 'Celtic' fields in Gotland represent the oldest identifiable phase. This type of arable landscape characterised the island in the period 500 B.C. to A.D. 200 . On the basis of the size of each field system, Lindquist characterised the farming system as based on bush fallow. Farming was probably carried on within a larger community. The shape of the plots reflects the mode of tilling: cross-ploughing with an ard (Lindquist 1974; Carlsson 1979; Windelhed 1984).

As land use was intensified in the second and third centuries A.D., cultivation was concentrated on small, heavily manured fields. This led to a new type of landscape with a marked boundary between, on the one hand, the infields and meadows and, on the other, common pastures and woodland. Farming was conducted on an individual basis, with close spatial connections between long-houses and fields, although often within the framework of larger communities in the same enclosures. This type of landscape overlays the 'Celtic' fields of Gotland (Lindquist 1974; Carlsson 1979) but can also be found in similar forms on the island of Öland and in 
the Swedish mainland provinces of Östergötland (Widgren 1983) and Uppland.

In the period A.D. 800 to 1200 , ideas on regular fallowing were widespread in many areas and the arable was divided into two or three separate fields. This led to overall changes in the physical layout of the townships. The whole idea of a two- or threefield system necessitates not only a redistribution of arable land, but also a concentration of the settlement, so that all farms have equal transport distance to their plots. Among agrarian-landscape researchers, there has been a general agreement that farming in strips is connected with these medieval reorganisations (Sporrong 1971; Lindquist 1976). Strip-parcelling has been seen as a product of the concentration of scattered settlements into a common village organisation and the major cause behind it was the introduction of regular field systems.

An underlying assumption has also been that the major changes between these three phases were connected with increases in areal productivity. A second assumption has been that both settlement forms and property rights reflect, in the first place, the degree of development of the farming system. Population increase has subsequently been seen as the main cause of changes in agrarian society (Lindquist 1974; Welinder 1975). In a long-term perspective, this is almost a matter of course. When, on the other hand, it comes to explaining actual changes in empirically investigated sites and regions, its explanatory power has, on the basis of a number of empirical tests, been shown to fail (Widgren 1989). Furthermore, such models, based on population increase, cannot explain the regional distributions of different agrarian landscapes.

During the last few years, geographical inquirers into early agrarian landscapes have therefore tended to adopt another approach. Instead of using the farming system as the main analytical tool, we have tried to concentrate on the landscape as an expression of property rights (Sporrong \& Widgren 1986). One of the main arguments in this way of approaching old problems has been that collective and individual rights to land should not be regarded as steps in an evolution in which collective rights to land must always be seen as original. As a result of this reorientation of agrarian landscape studies, investigations are now going on in the province of Dalarna on inheritance rules and subdivided fields (Sporrong 1988), in the province of Smaland on the role of land ownership in medieval colonisation (Tollin 1987) and in Västergötland (the present paper).

The project of which this is a report is entitled "The origin of subdivided fields in. western Sweden'. In the planning phase, it started as a project oriented towards the period between the Middle Ages and the seventeenth century, but, through the finding of a new type of field evidence, it came to include the study of similar forms of land division of a much earlier date.

The background is as follows: in the western part of Sweden, farming in the seventeenth century and probably also during medieval times was carried ou with continuous cropping in a simple form of infict. system. In the south-western parts of Sweden, neither two-, three- nor four-field systems were common. Usually this meant that the same area was cropped annually, with only minor parts in fallow (Frandsen 1988). However, in spite of the absence of regular fallows and the accompanying arrangements of fields, this area (Bohuslän and southern parts of Västergötland) provides a series of early maps depicting subdivided, strip fields.

Furthermore, the south-western parts of Sweden were also untouched by real assessment in medieval times. In the eastern parts of Sweden, the land was assessed either in 'attungar' or 'markland', which served as definitions of the shares. These real assessments have previously been interpreted as one of the prerequisites of subdivided fields (Göransson 1985).

To summarise, neither cropping regulations nor real assessment carried out by central authorities can be used to explain the existence of subdivided fields in this part of Sweden. The choice of this area for detailed investigation is thus also a choice among explanations. In these regions, the social aspects (property rights and inheritance rules) naturally come into the focus of explanation. The fact that this area in medieval times was divided between two political realms - Denmark/Norway and Sweden with different systems of inheritance makes the research area even more interesting.

The seventeenth- and eighteenth-century map evidence from the area showed a lot of examples of subdivided fields - from the fully fledged, open fields of some clayey areas in Bohuslän and in the valleys of västergötland to the partially consolidated, partially subdivided fields of the uplands of Västergötland. Special attention was given to this latter area because of the recent recordings of the Survey of Ancient Monuments. A large number of the localities with ancient fields showed signs of regular parcelling into strip fields ranging from some 7 to 40 metres wide. At first glance, these localities seemed to offer the ideal way of documenting and dating medieval open fields. But, as will be shown in this paper, all the evidence gathered until now indicates that this type of field was in fact pre-medieval and had its origin around the birth of Christ.

The findings of strip parcels in a prehistoric context is not totally new. in Sweden (cf. Klang 1980). It is, however, not until now, when they have been found in such a number of localities in a small area, that we can speak of a morphologically and chronologically well-defined type of landscape.

The investigations of these fields have been divided into two phases. This paper is a report on the first phase. This included the detailed mapping of three localities and archaeological test excavations in one of the localities (section II), a discussion of the relevance of this evidence in connection with the problem of medieval open field (section III) and a metrological analysis of the plans (section IV). The aim of the paper is to sum up the evidence and 


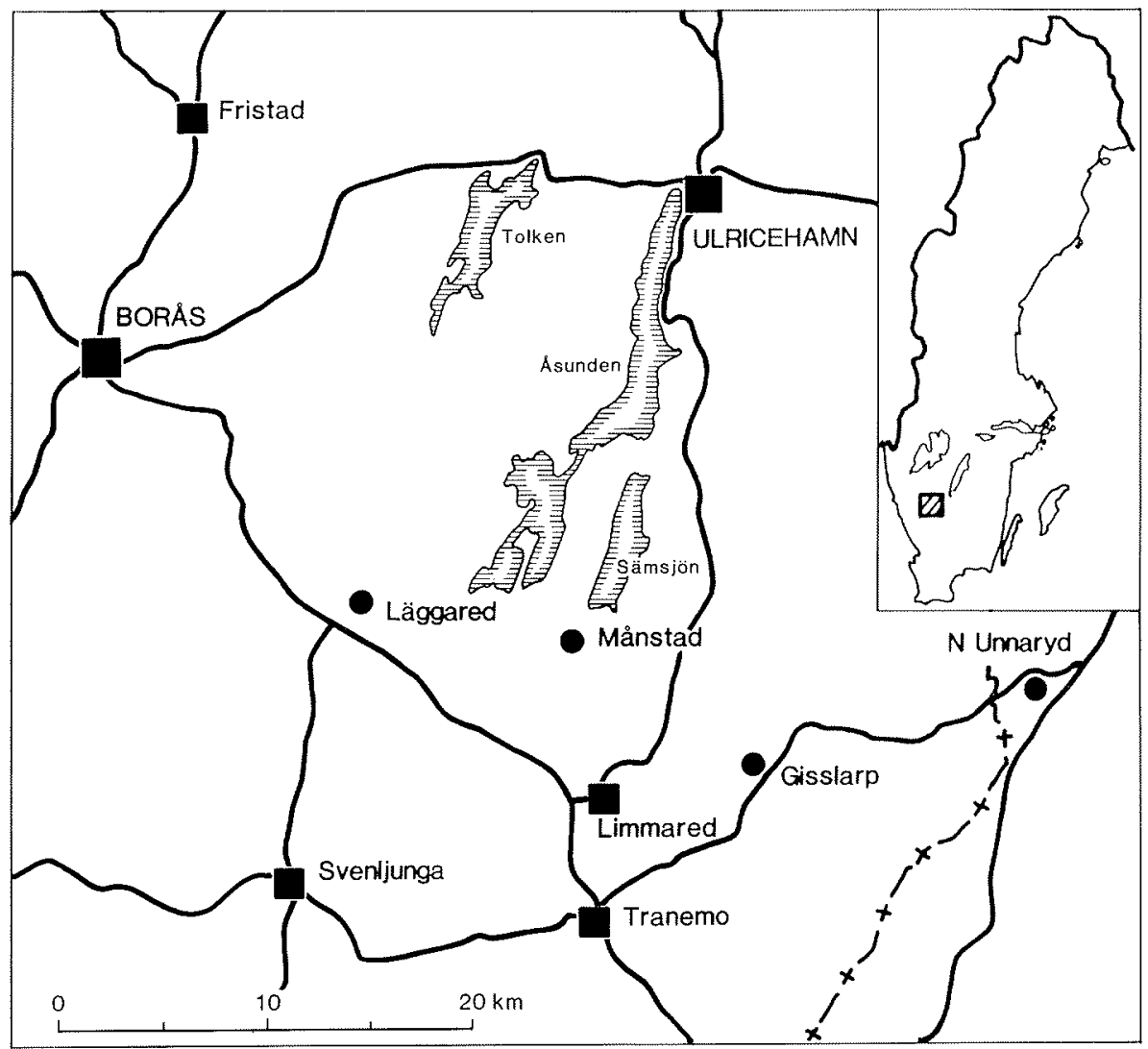

Fig. 1. Location of investigation area. Localities surveyed on the ground are marked with dots.

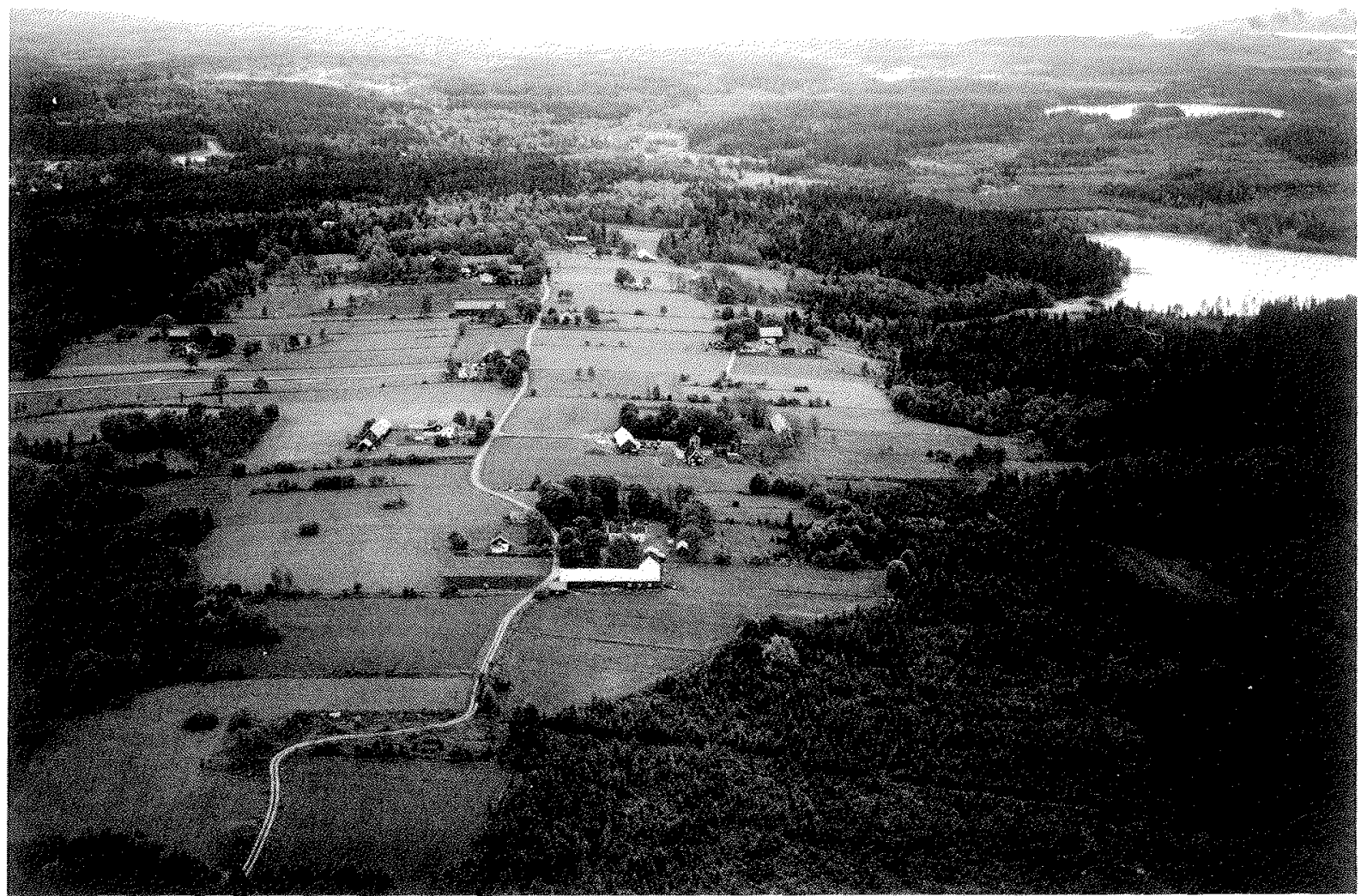

Plate I. Läggared, Hillared parish, from the SW. The picture shows mainly the central, continuously cultivated land on the central part of the drumlin. Remnants of the old strip pattern can still be seen in the present arable. The farms in the south-eastern slope to the right of the main road are in the same positions as on the 17th-century map ( $f$. fig. 2.). Photo: Jan Norrman. 


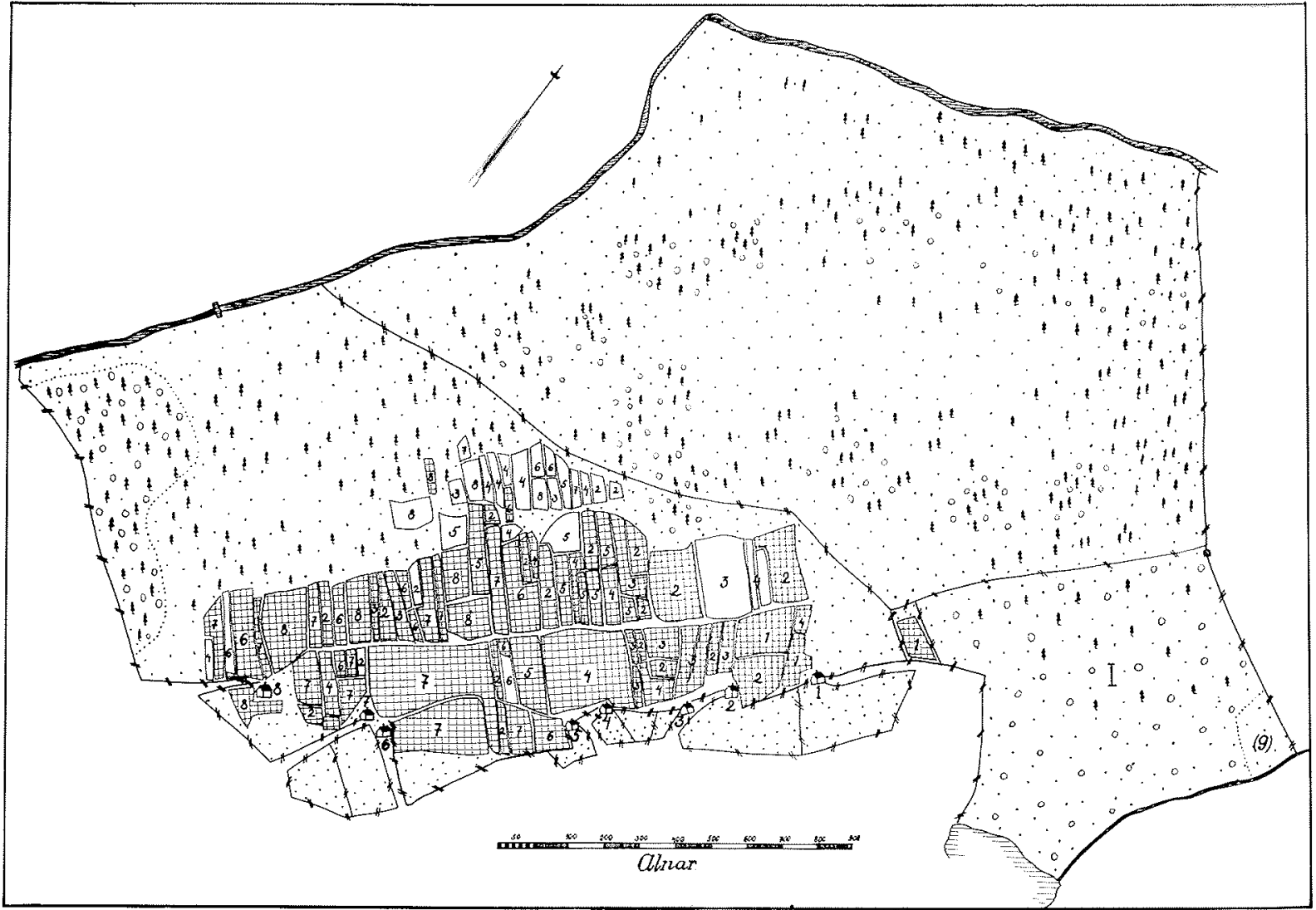

Fig. 2. Läggared, Hillared parish, Västergötland 1648. Close to each farmstead are larger, block-shaped fields. The strip fields in the western part give the impression of having been added successively as the cultivated area was expanded to the north-west (From Erixon 1960).

A

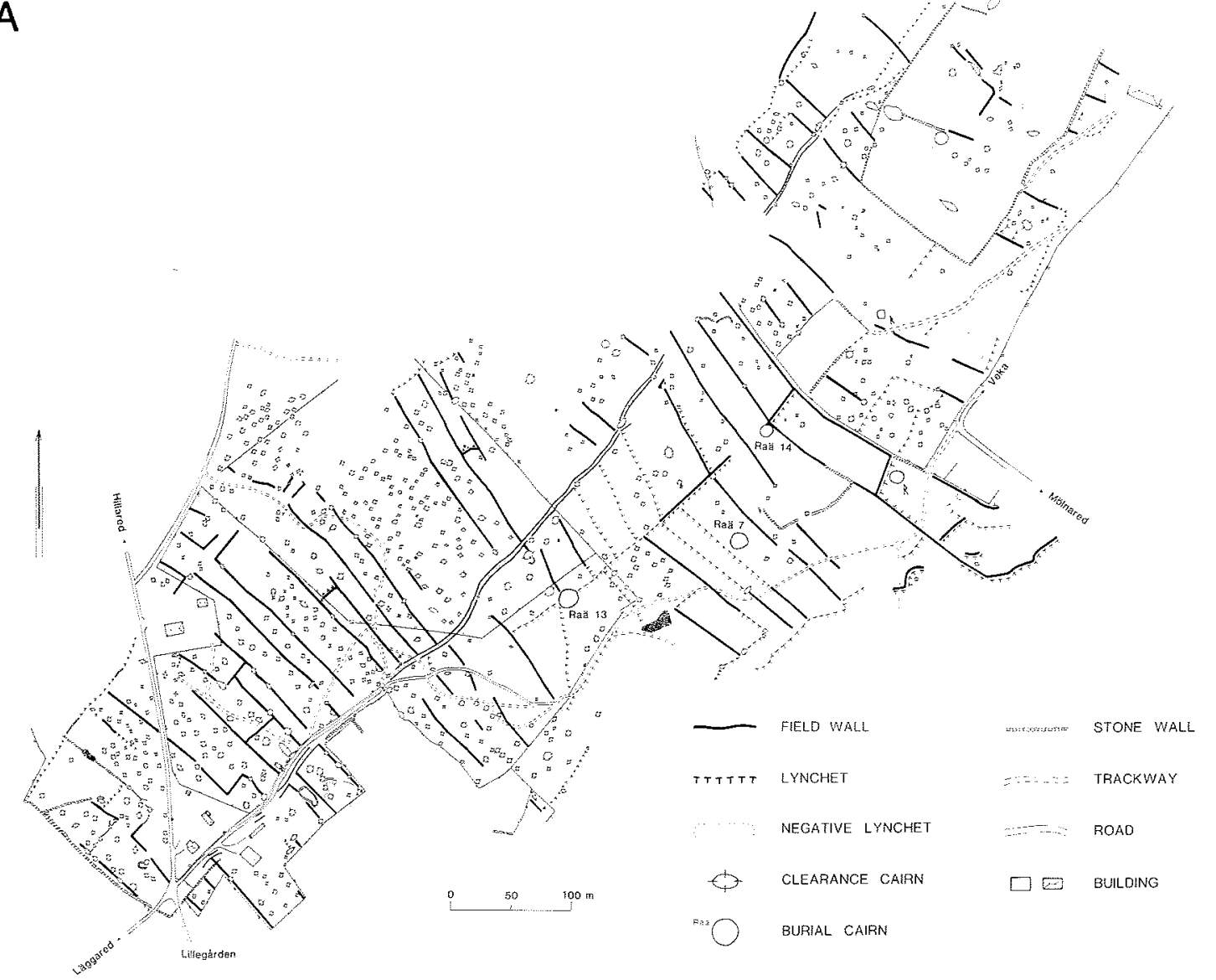




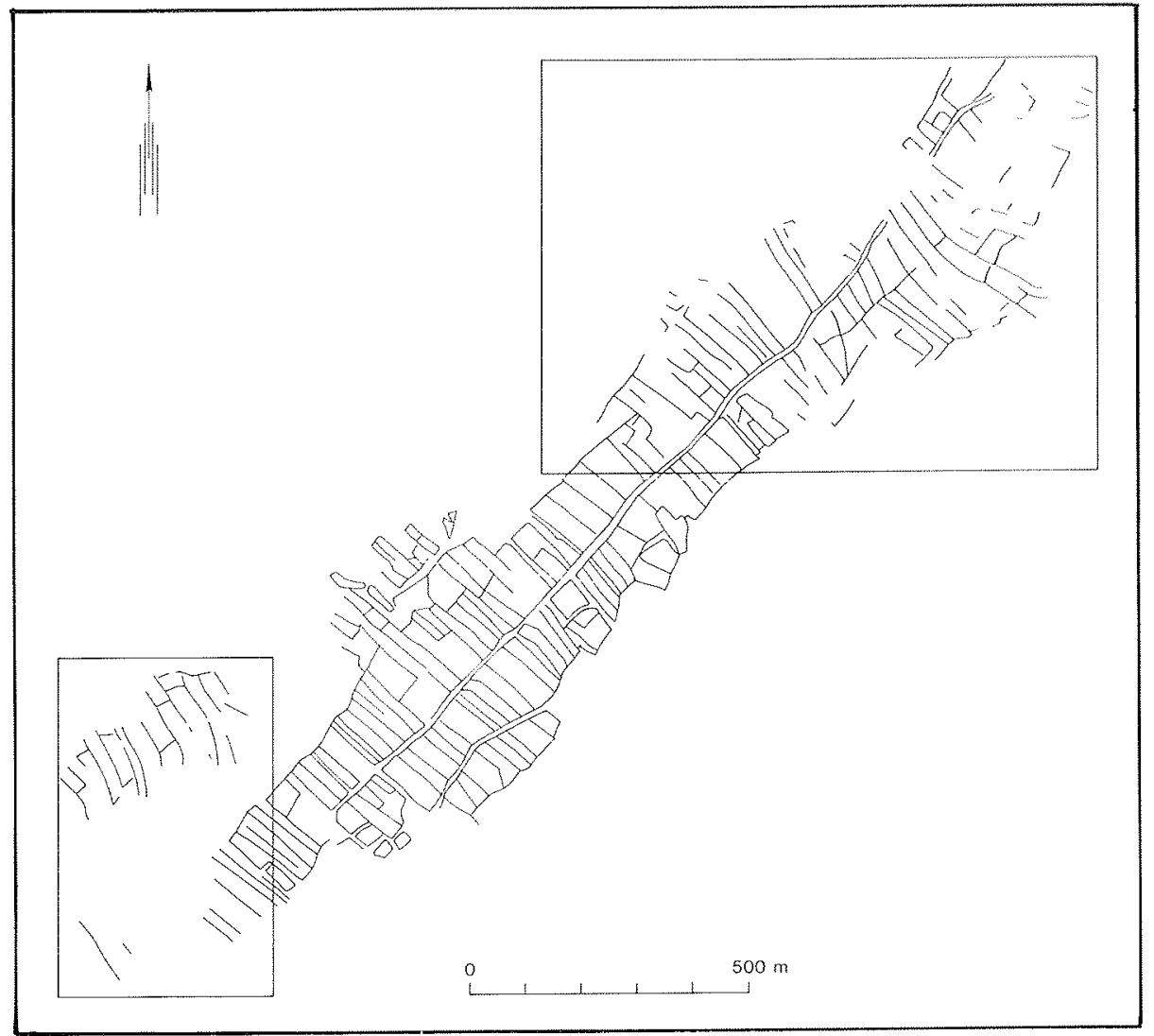

Fig. 4. Field pattern at läggared. Based on ground surveys of fossil fields (within the frames) and a cadastral map dating from A.D. 1700.

B

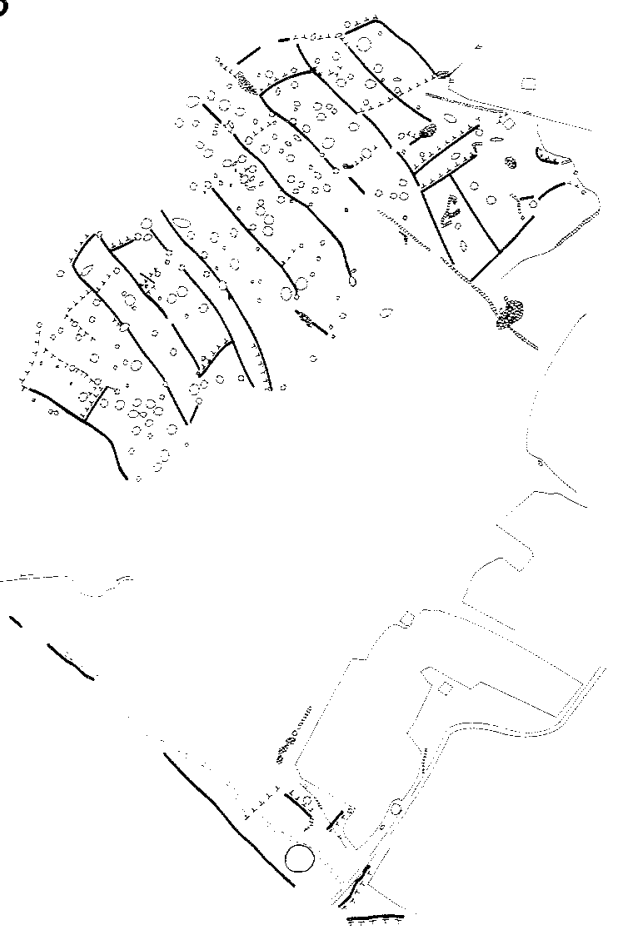

Fig. $3 a$ and $b$. Fossil fields in Läggared. Surveyed by Catharina Mascher, 1987-88. present a hypothetical, developmental sequence as a basis for the second project phase, which is aimed at problem-solving field investigations.

\section{FIELD EVIDENCE IN KIND, VÄSTERGÖTLAND}

Kinds bärad (jurisdictional district) is located some 50 kilometres east of Gothenburg in a hilly landscape above the marine limit. From the agricultural viewpoint, the most valuable areas in this landscape have always been on the crests of the moraine formations, where the unwashed till contains a large fraction of fine-grained soils, as opposed to the lower parts, in which either boulders or bogs predominate. Among the forms of moraine, long, drumlinoid ridges running in a NNE-SSW direction predominate. On the seventeenth-century maps, cultivation and settlement are concentrated on the eastern and south-eastern sides of these ridges. The map of Läggared (Fig. 2) presents a characteristic settlement situation from this period.

The localities with fossil fields which have been found in this area during the 1980s are often located in direct connection with the seventeenth-century, arable fields, as documented on the cadastral maps, but only seldom can seventeenth-century and later cultivation explain the fossil forms.

In this project, three localities were fully documented by detailed ground surveys on the scale 
of 1:1000 during the years $1985-88$ (Fig. 1). Mapping was also carried out in 1986 by the Jönköping County Museum of the locality of Norra Unnaryd, from which data will be used in the metrological analyses. A preliminary report of the investigations has previously been printed (Widgren 1987).

\section{LÄGGARED, HILLARED PARISH (Plate I).}

The seventeenth-century map (Fig. 2) of this loosely grouped hamlet has been published by Erixon (1960). It gives a good impression of the conclusions that can be drawn on the basis of a retrogressive analysis of the map and on inferences from previous research in neighbouring areas. The fields and settlements are located on top of a long drumlin running in a NNE-SSW direction. The farmsteads were lying isolated from each other on the eastern slope of the elevation and each of them had its arable partly in large blocks around the farmstead and partly in intermixed strips in the peripheral parts of the arable land. A simple, morphogenetic interpretation of this map suggests that in the primary stage each farm had its arable separated from the other land in large, enclosed areas around the farmsteads. As more land was taken into cultivation piece by piece on the formerly common grasslands, intermixed strips developed on the periphery of the arable area. Stages in such a development in the neighbouring Falbygden area have been discussed on the basis of a series of cadastral maps (Lindgren 1939). In the central parts of that area, the villages developed into concentrated villages with a three-field system.

This interpretation of the development of subdivided fields was - to say the least complicated by the ground survey and analysis (Fig. 3) (Mascher 1988). In 1985, the Central Office of National Antiquities recorded fossil strip-fields to the north of the present fields and later an area of the same type was found in the south. Furthermore, on a later map dating from 1700 , it turned out that the whole arable area was then divided into working parcels in the form of strips. The earliest map (Fig. 2) evidently only showed the tenure parcels and their block shape did not in any way depict the actual strip patterning of the field. As can be seen from Fig. 4, the pattern of the fossil fields has a general resemblance to the strip pattern documented on this somewhat

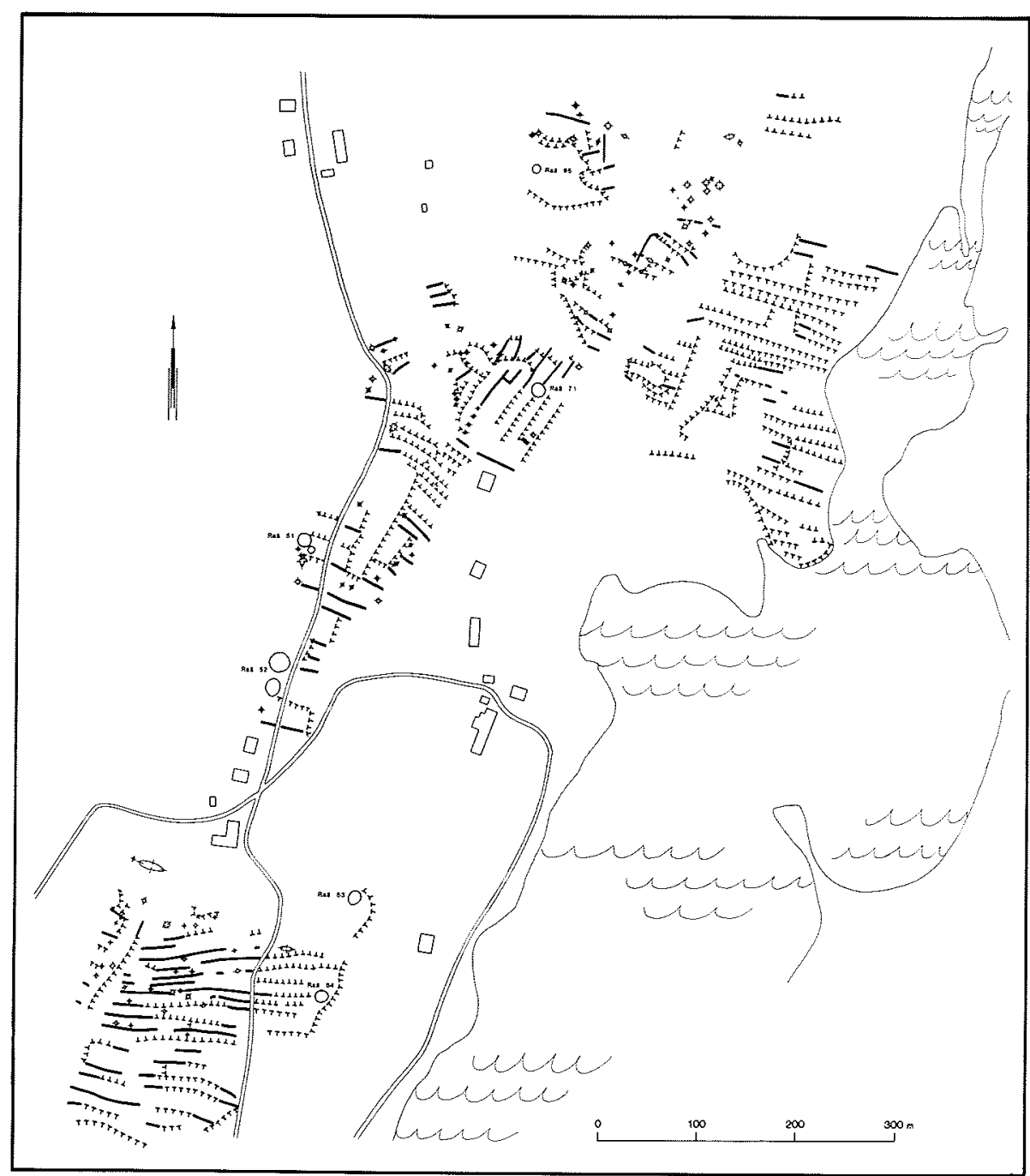

Fig. 5. Fossil fields in Gisslarp, Nittorp parish, Västergötland. Surveyed by Aadel Vestbö, 1986-87. Legend see Fig. 3. 


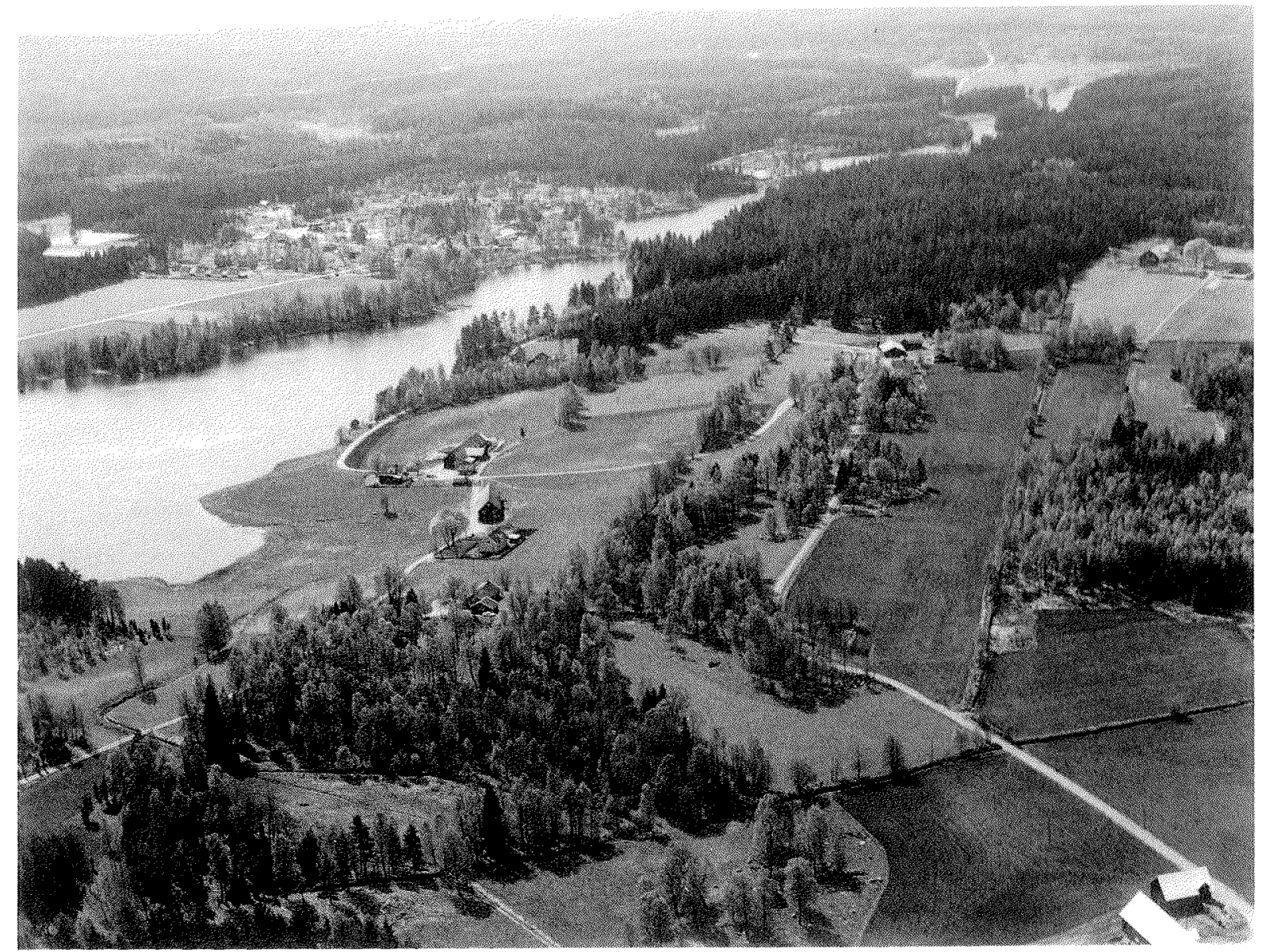

Plate II. Gisslarp from the N. The fossil fields are situated in the deciduous woodland in the center of the picture and in the spruce forest immediately south of the open land. Photo: Jan Norrman.

later map. It is clear from this analysis that the strip pattern documented on the seventeenth- and eighteenth-century maps was a physical structure which had a much earlier origin. Contrary to the 'traditional', retrogressive analysis, the emergence of strip parcelling cannot be attributed to late medieval or early, modern, piecemeal colonisation.

Taken together, the area with strip fields documented either on maps or in the field covers an area of over 70 hectares. Judging from this size, it is already possible to say that the fossil fields have little relation to the historically known, farming systems in the area.

The fossil field boundaries consist of low banks of stones and earth. The content of the walls varies with the surrounding soils and with the degree of clearing. In some strips, the land is well cleared and stones from the field have been placed not only in the banks, but also in clearance cairns. These areas may well have been tilled with an ard. Other strips are much less well cleared and only small patches within them seem to have been under cultivation.

Besides the many clearance cairns, there are four burial cairns in the area, which on the basis of their form can be given a rough dating to the Bronze Age or the Early Iron Age (1500 B.C. to A.D. 500). All of them are located on the fossil fields and two of them seem also to overlie lynchets. Their relation to the fields is a very strong indication of a prehistoric date for the field pattern.

\section{GISSLARP, NITTORP PARISH (Fig. 5, Plate II)}

Looking at it superficially, the locality of Gisslarp showed all the aspects of a partially deserted, probably medieval, open field. The type of boundary (earthen banks with many stones $c f$. Plates III and IV and the breadth of the strips (between 7 and 30 metres) has many parallels with the radio-carbondated, medieval and later fields at Brunsbo (Lindquist 1976) and Åsle (Sporrong, pers. comm.) less than 100 kilometres further north in Västergötland.

But here also, further analysis in the field showed that the parallel banks were the oldest identifiable phase. Within the locality could be found small, irregular fields that - according to map evidence were tilled in the eighteenth and nineteenth centuries. These areas had no morphological similarities to the underlying land division. While the younger fields may well have been tilled by an ard, the underlying land division takes very little account of slope and the land is generally very 


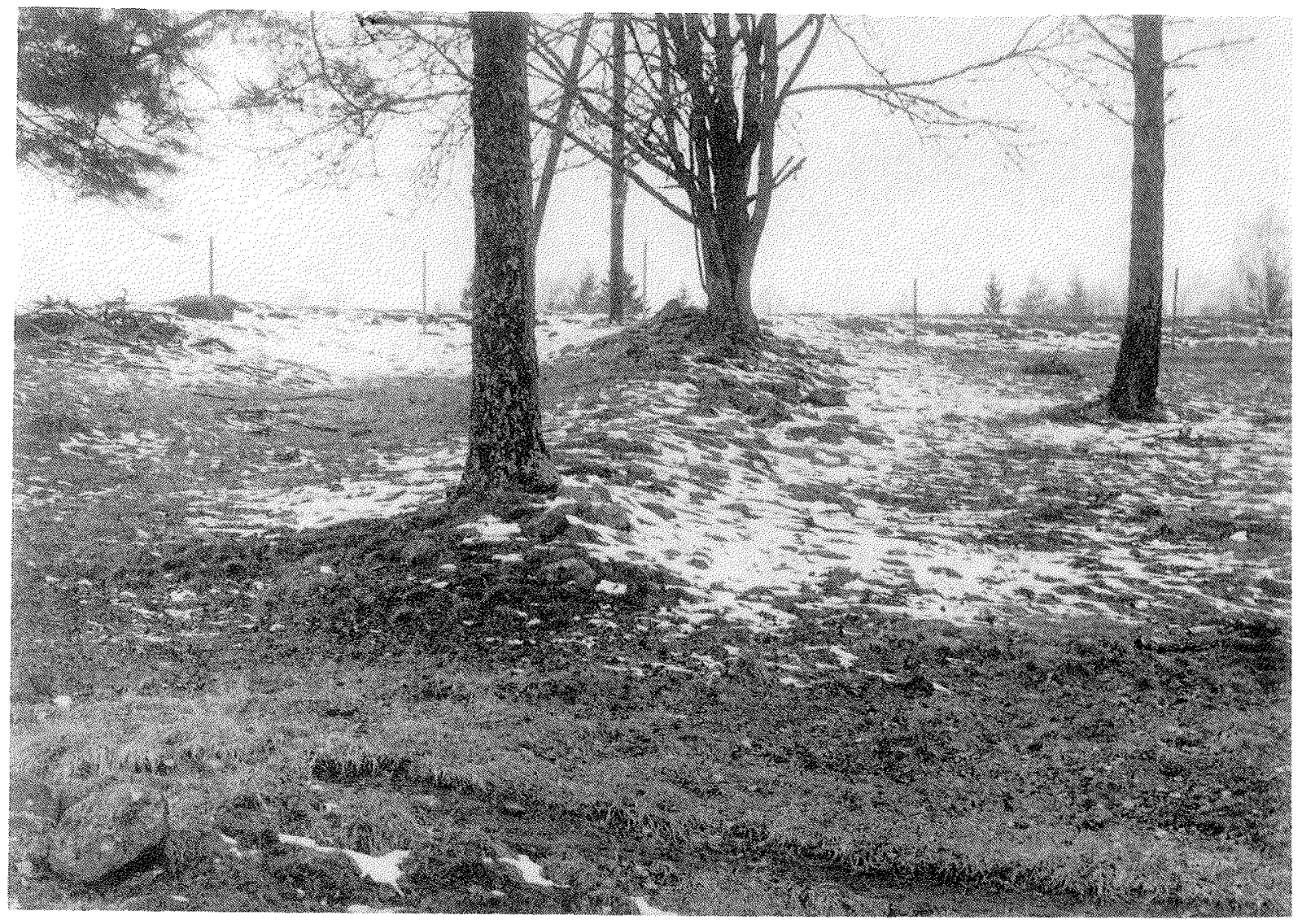

Plate III. Field wall at Gisslarp. Photo by Anders Johansson, April 1986.

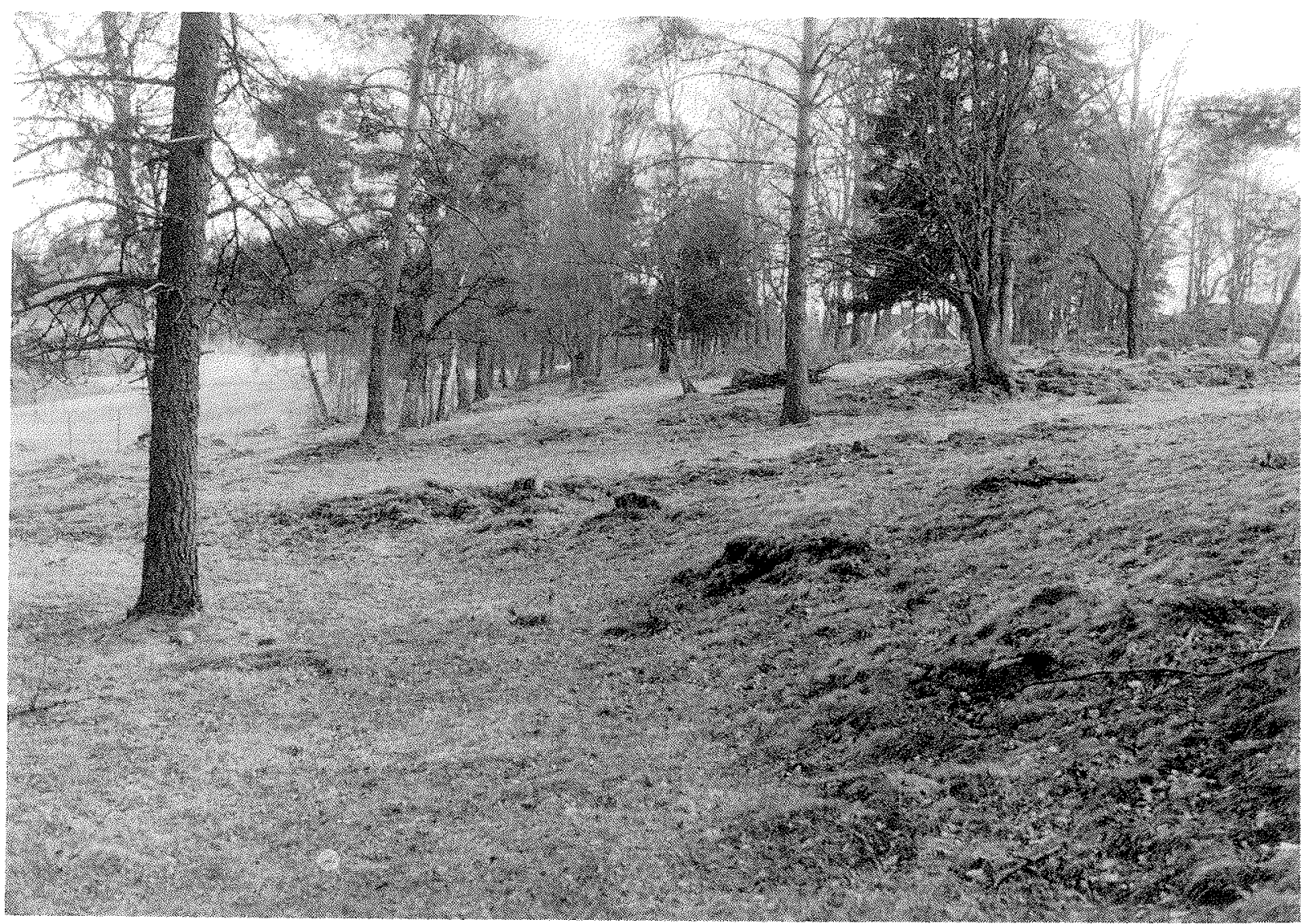

Plate IV. At the front a negative lynchet. The land to the left has been tilled. In the rear, two parallel field walls delimiting a strip field. Gisslarp. Photo by Anders Johansson. 


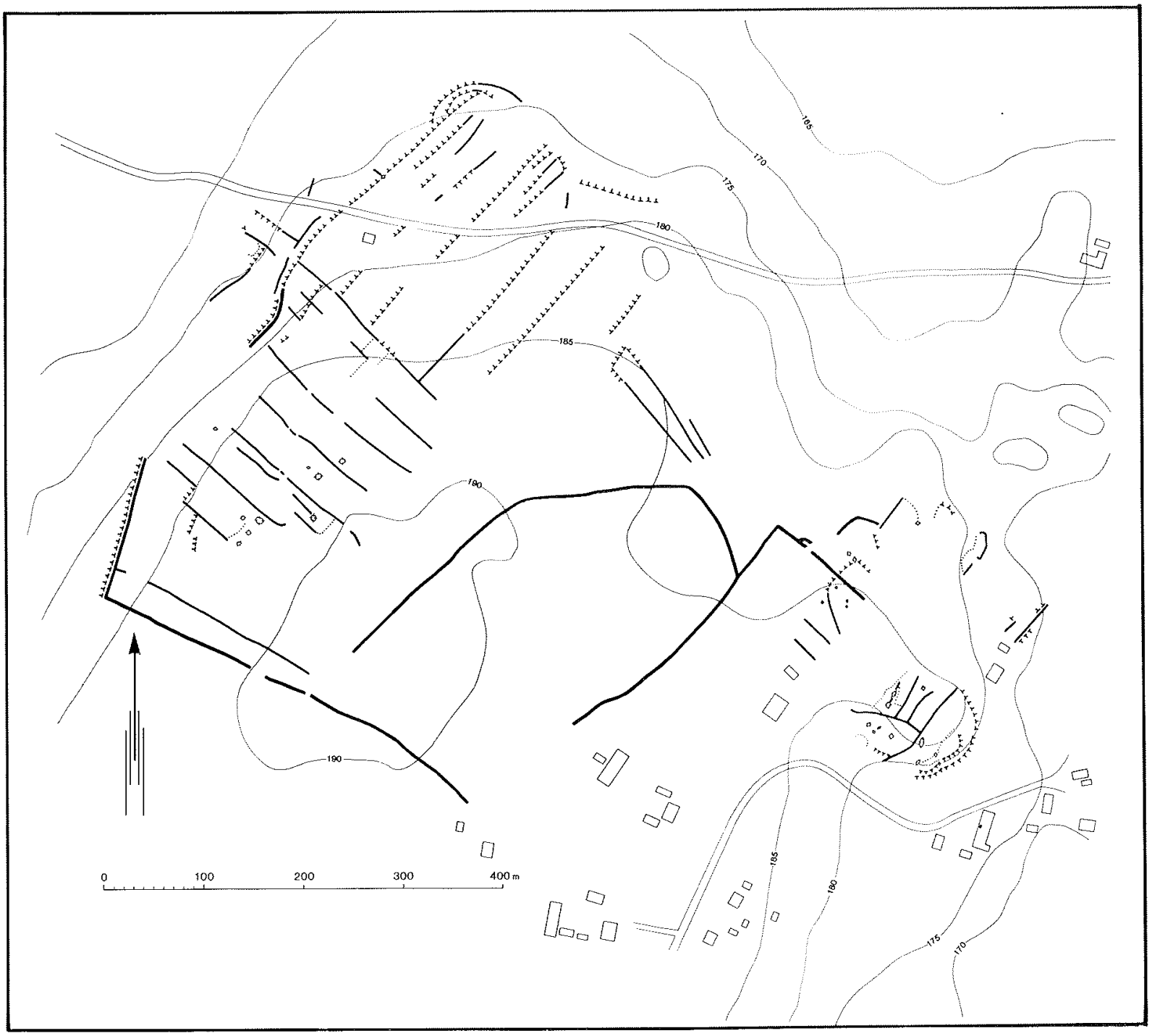

Fig. 6. Fossil fields at Månstad, Månstad parish, Västergötland. Surveyed by Per-Eric Ullberg Ornell and Mats Widgren, 1986. Legend see Fig. 3 .

poorly cleared of stones. One clearly gets the impression that it has never been tilled by a traction implement, but rather by a hoe or some other hand implement. The strip fields in this locality thus represent an obviously older layer of the agrarian landscape than that documented on the early maps. They represent another way of dividing the land and probably also another technique of tilling.

On the regional scale, there is a spatial covariation between large Bronze Age or Early Iron Age cairns and localities with these types of ancient fields, which in itself suggests a chronological connection. In this locality, there are also signs of stratigraphy: some of the cairns, in fact, seem to have been constructed on top of previously arable fields.

Furthermore, a closer study of the locality showed that the fossil fields extended far beyond the historically used arable area, not only in the central parts of it, but also further south and north. A plan of the fields can be seen in Fig. 5 (Vestbö 1988). The fossil strip-fields today cover an area of 24 hectares but may originally have covered some 35 hectares.
These figures should be compared with the roughly 5 hectares of arable land in the eighteenth century.

\section{MÅNSTAD, MÅNSTAD PARISH}

On the outlying lands of the hamlet of Manstad, a similar locality is found. It differs from Nittorp mainly in the breadth of the strips and in the clear and simple plan. Located north-west of the core arable area of the hamlet, it probably represents a 'high-water mark' of cultivation. As can be seen from the map (Fig. 6) it is dominated by six strips some 40 metres wide running in a NW-SE direction. The parcels in this southern 'furlong' were measured in the field and the following mean values are based on two measurements in each parcel: $41.6,39.7,38.5$, $41.6,44.5$ and 44.5 metres respectively. The average breadth, which is supposedly close to that intended, is 41.7 metres.

At right angles to these fields can be found another group of six wide strips bounded by lynchets, similar 
in plan, although less regular in their breadths. Within the strips, there are arable plots, bounded by earthen banks, lynchets or very diffuse signs of clearing. Some areas of the fields are well cleared of stones, others much less well. It seems clear, therefore, that the strip fields are not the product of the tilling, as such. Furthermore, no signs of an oxdrawn ard or plough can be documented; instead of the rounded form usually associated with ard tilling, the negative lynchets were jagged and irregular, as if worked with a hand implement. To conclude, the regular division has nothing to do with the tilling. Its main function was to regulate the use of the land.

Besides the irregular forms associated with tilling, there were also indications of a more regular infilling, consisting of secondary divisions of the wide strips into halves and quarters of the original breadth

Within this locality, three field boundaries have been excavated. In one of the main boundaries, fragments of charcoal were found in the contact layer between the earthen banks or lynchets and the original land surface. In another trench, charcoal was collected under a 50-cm-thick lynchet, where large pieces of charcoal had been preserved under the topsoil. Four charcoal samples from this probable clearing horizon yielded dates between 2400 B.P. to 1845 B.P. To judge from these dates the land was cleared and divided some time during the period 500 B.C. to A.D. 200 (cf. Figs 7-9).

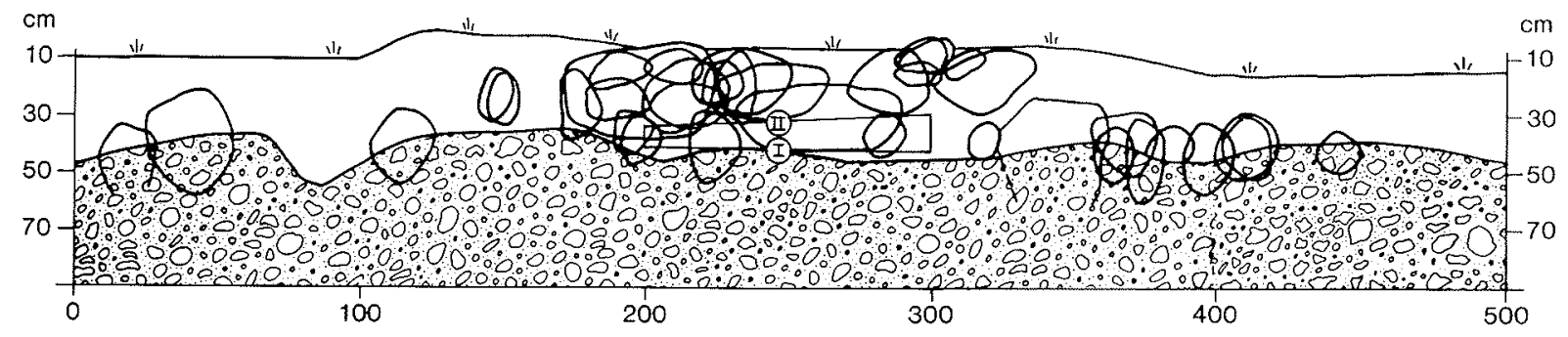

(I) St $10676 \quad 2400 \pm 185 \mathrm{BP}$

(II) St $106772130 \pm 130 \mathrm{BP}$

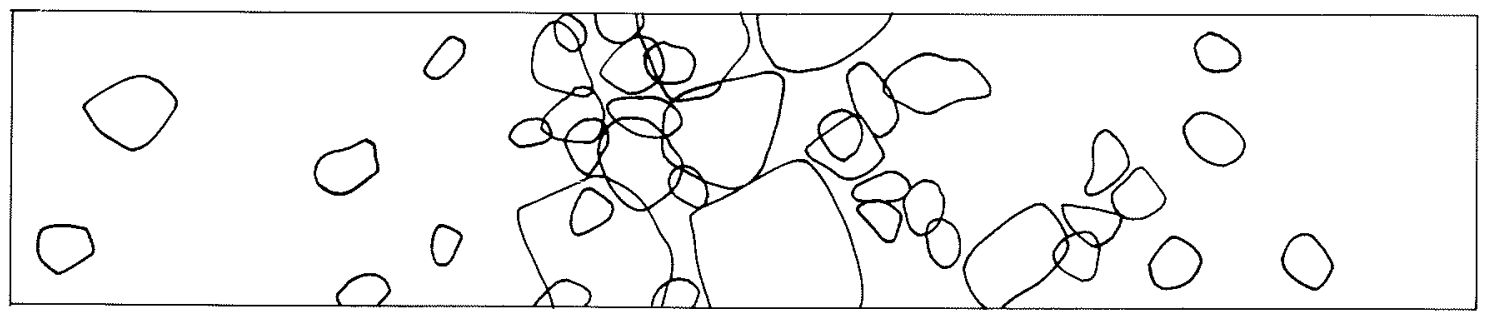

Fig. 7. Trench through major field wall at Månstad. Plan and projected section. Locations of charcoal samples shown with Roman numerals. Charcoal collected in a volume indicated by the box in the section.
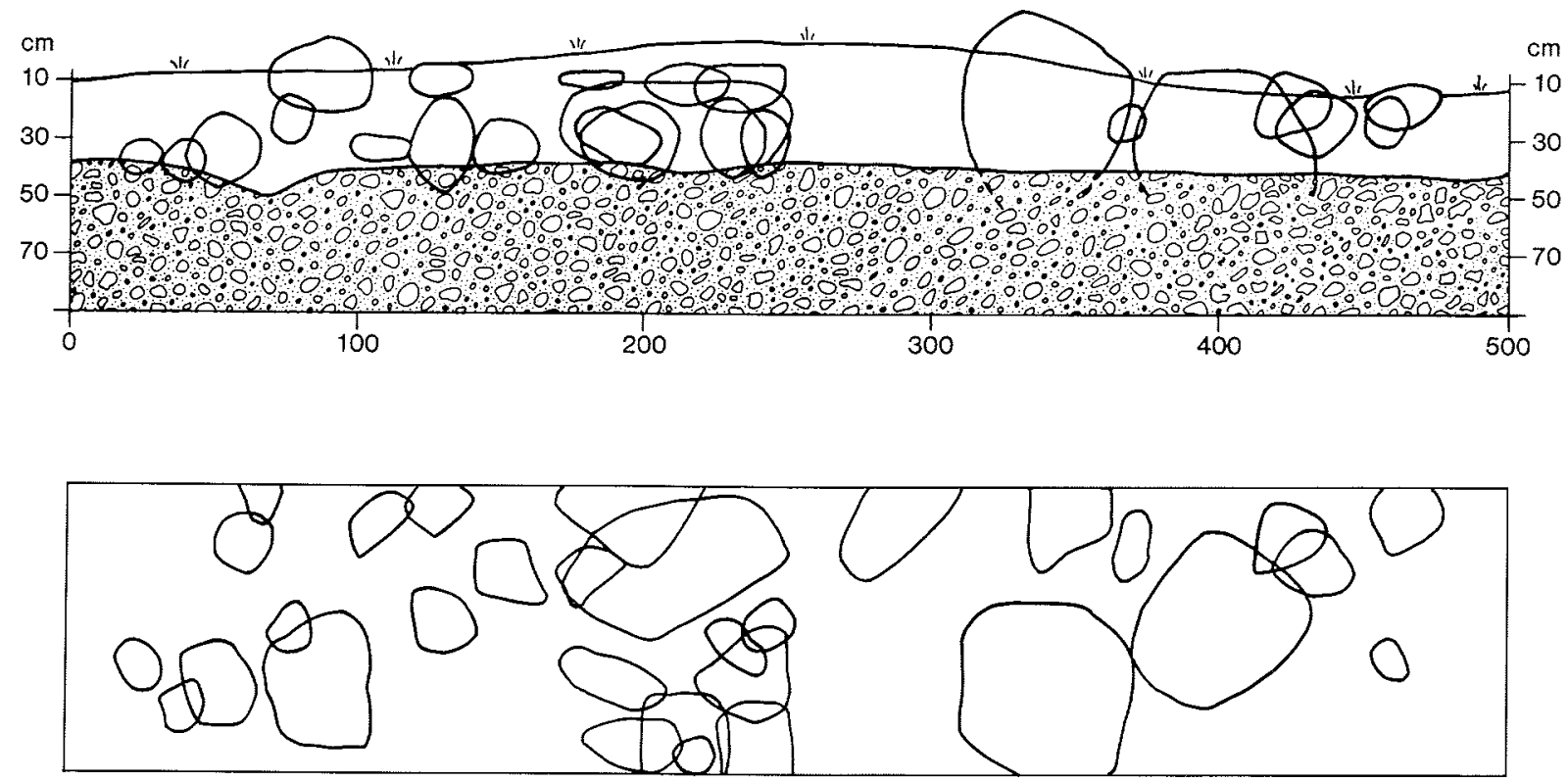

Fig. 8. Secondary field boundary at Månstad. Plan and projected section. Very sparse occurrence of charcoal. 


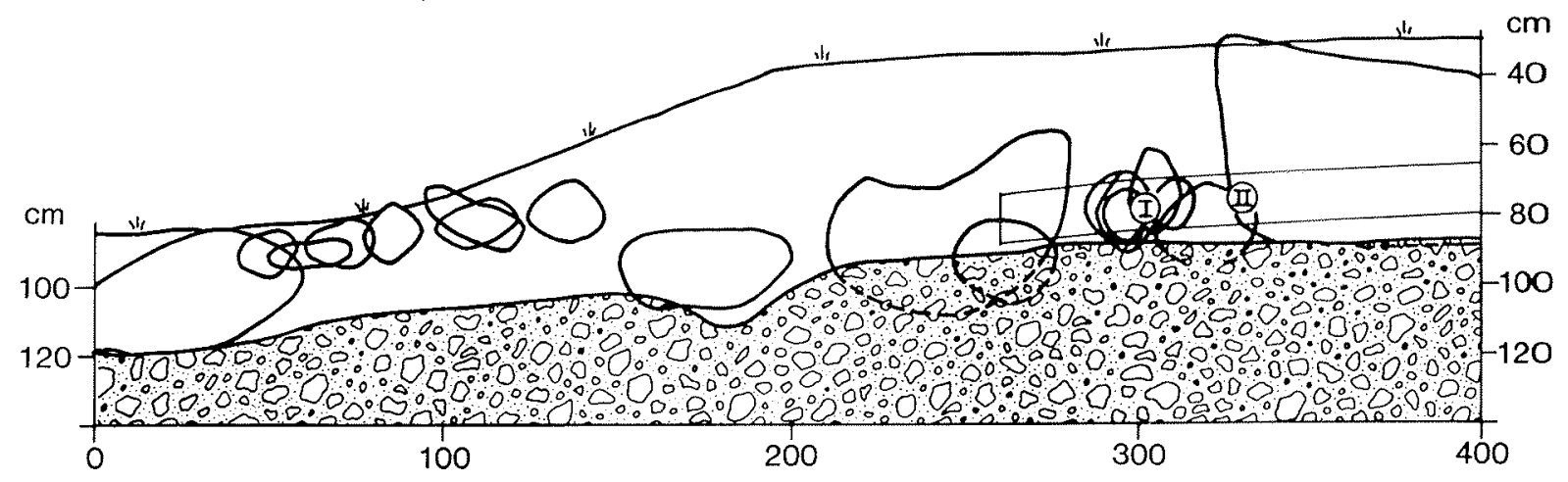

(I) St $10678 \quad 2345 \pm 250 \mathrm{BP}$

(II) St $106791845 \pm 120 \mathrm{BP}$

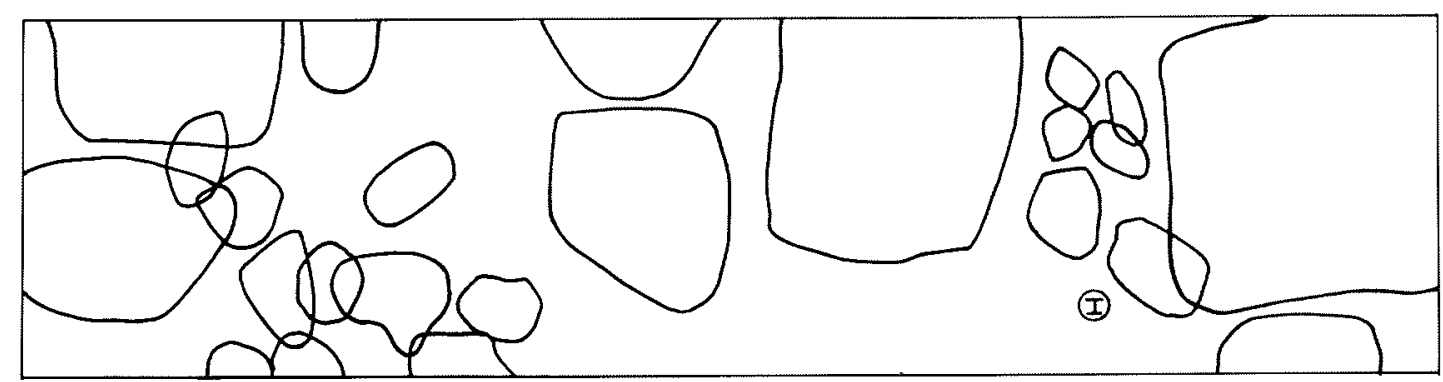

Fig. 9. Lynchet at Månstad. Plan and projected section. Charcoal samples from a fossil land surface under the lynchet.

\section{PLANNING IDEAS}

The regular, long strips found in these and a number of other localities in the area naturally raise questions as to the degree of measurement and planning involved in the layout. The three localities presented here differ in the breadths of the strips and in their overall planning. They can, however, be seen to represent a continuum from the exceptionally simple plan of Månstad, with wide parcels, through the complicated plan at Läggared, which still has a predominance of rather wide parcels, to the small and sometimes irregular parcels of Gisslarp. The question is, whether they also represent stages in development.

In the case of Manstad, there is no need for any sophisticated, quantitative methods to draw the conclusion that the planning idea is based on six equally large strips laid out parallel to each other. Maybe the six strips laid out at right angles to the north-east were also planned as another 'furlong' for the same six shareholders?

This is, of course, sheer speculation, but the field map is in itself a very clear illustration of the ideas presented by Fowler on the origin and development of planned, prehistoric fields in the British Isles (Fowler 1983, p. 106). The land may, according to this model, originally have been cleared in equally wide strips, almost like a Waldbufen-siedlung. As tilling within these areas became more permanent, arable plots were developed within the wider strips. Subdivision of holdings led to another type of infilling, when the original strips were divided into halves or quarters. In the terms used by Hannerberg, the parcels of Månstad would represent a frame planning for future cultivation (Hannerberg 1976, p. 23). This type of development from wide strip parcels via a successive infilling to a checker-board pattern of block-shaped fields has also been discussed on the basis of evidence from the Netherlands (Brongers 1976, p. 57) and Gotland (Carlsson 1979, p. 59). A further analysis of the plans of Gisslarp and Läggared will be carried out in section IV.

\section{DISCUSSION}

Two lines of discussion emerge from these new finds. One concerns the circumstances under which these strip fields were developed and their relation to the antecedent types of agrarian landscapes in the area. With this line of discussion is connected the problem of the function of the parcels: whether we are to interpret the parcels mainly as working parcels or as parcels of land-holding. This brings us to the other line of discussion, which concerns the similarities, the links (in ideas as well as in physical structure) between these strips and the later, medieval, subdivided fields.

The more timid answer to the first line of discussion would be to interpret the strips as working parcels adjusted to the type of tilling and/or to say that the division of land served the purpose of demarcating different areas under cultivation in a long-fallow system. In the contemporaneous field 
systems on Gotland, it has been shown that the small working plots had a modular distribution of their area, indicating that the working time spent on each of them could explain the size distribution (Lindquist 1974). This might be the case in Gisslarp, where the size of the parcels represents a day's or half a day's work. But the characteristic trait in the material is that only smaller areas within each parcel show signs of actual tilling. They may possibly have been intended for arable land but were never fully cultivated.

But what really stands in the way of the bolder conjecture that these fields were subdivided property in a community of peasants? One factor is, of course, the problem of evidence - it will always be difficult to dig up forms of tenure. Another obstacle is that the whole debate on the origin of open fields has tended to treat the subdivision of fields as a specifically Western-European and medieval topic. To solve the problem of the relations to antecedent phases, it is therefore necessary to first take up the second line of discussion - that of the relation to the later, medieval, subdivided fields.

\section{SUBDINDED FIELDS?}

Most authors are very cautious about drawing parallels between prehistoric field systems and the medieval open fields: tenure and land-holding cannot be read from the geometrical forms of fields alone. As has been remarked by Dodgshon, long or rectangular fields may have been created by the technique of ploughing, i.e. they may be working parcels rather than tenure parcels, or they may have represented separate holdings, without any intermixture of their property (Dodgshon 1980, p. 63).

In the cases I have discussed above and in half a dozen other, more superficially surveyed, localities, however, it seems quite clear that the parcels are generally not the unit of work, something which was clearly shown in the Månstad locality, where small working plots were identified within the frames of the parallel walls. On the other hand, the fields are usually too narrow to have represented separate, consolidated holdings. It is therefore difficult to explain these fields in any other way than as a land division between land-holders in a farming community, i.e. a subdivided field in the medieval sense.

The claim that these prehistoric fields were really subdivided between land-holders may seem provocative in light of the much-debated origin of medieval open fields. But, logically, there is much in that debate that opens up the possibility of seeing the subdivision of fields as an element which had its own rationality - and this not only in the context of the European, medieval, open-field village. From this, it follows that subdivided fields must not be explained either on the basis of other elements in the typical, open-field village, as Dahlman does, or by the presence or absence of any implicit or explicit markets in grain or insurance or whatever in medieval Europe as other economists do (Dahlman 1980; McCloskey 1976).

Many of the contributions from economists have been based on the assumption that subdivided fields were in one way or another costly. The explanatory efforts have been aimed at finding other benefits which would outweigh these costs. Against this, Fenoaltea has recently argued that these costs have not been proved, but generally only taken for granted as an effect of the traditional way of looking at the problem. He further argues that not only were the costs of subdivision, compared with consolidated holding, non-existent, but on the basis of the problem of labour scheduling over a large territory with differences in local climate and soils, the subdivision of fields was also economically superior to consolidated holdings (Fenoaltea 1988).

If subdivided fields thus have a rationality of their own, regardless of the other types of property rights and farming systems with which they are found, it is natural to see subdivision as an element which has come and gone over time.

This long-term approach to the problem of subdivided fields has many parallels in the antievolutionary statements made by Gudmund Hatt in the 1930s. Hatt then claimed that individual and communal property were equally old and that sometimes the one and sometimes the other of these two fundamental tendencies gained the upper hand, favoured by technical or social conditions (Hatt 1939). Thus, planned and communal arrangements of fields may in the same area be followed by a more gradually developed spatial organisation centred on the individual farmstead.

Similar arguments about regular land divisions on quite a different scale have been put forward by Andrew Fleming in a paper on the large, prehistoric, coaxial field systems in the British Isles. He says,

It is as if the idea of coaxial land divisions or perhaps beliefs about axiality in the local landscapes could lie dormant for centuries, to reemerge from time to time in certain circumstances (Fleming 1987, p. 198).

Subdivided fields thus cannot be discussed mainly on the basis of evidence from medieval Europe. Similar ways of dividing land have always been a potential development. These general conclusions on the origin of subdivision lead us back to the first Iine of enquiry, that of the antecedent phases. If we accept that subdivision of fields may have emerged in different time periods at different places, we still have to further define the social and ecological environment in which strip fields emerged.

\section{ANTECEDENT PHASE: CLEARANCE-CAIRN FIELDS?}

As to the forms antecedent to the regular, subdivided fields in southern Sweden, we have as yet very little precise knowledge. But the recent recordings of large, clearance-cairn fields in the provinces of Småland and Västergötland may play a central role in our understanding of the processes that led to 


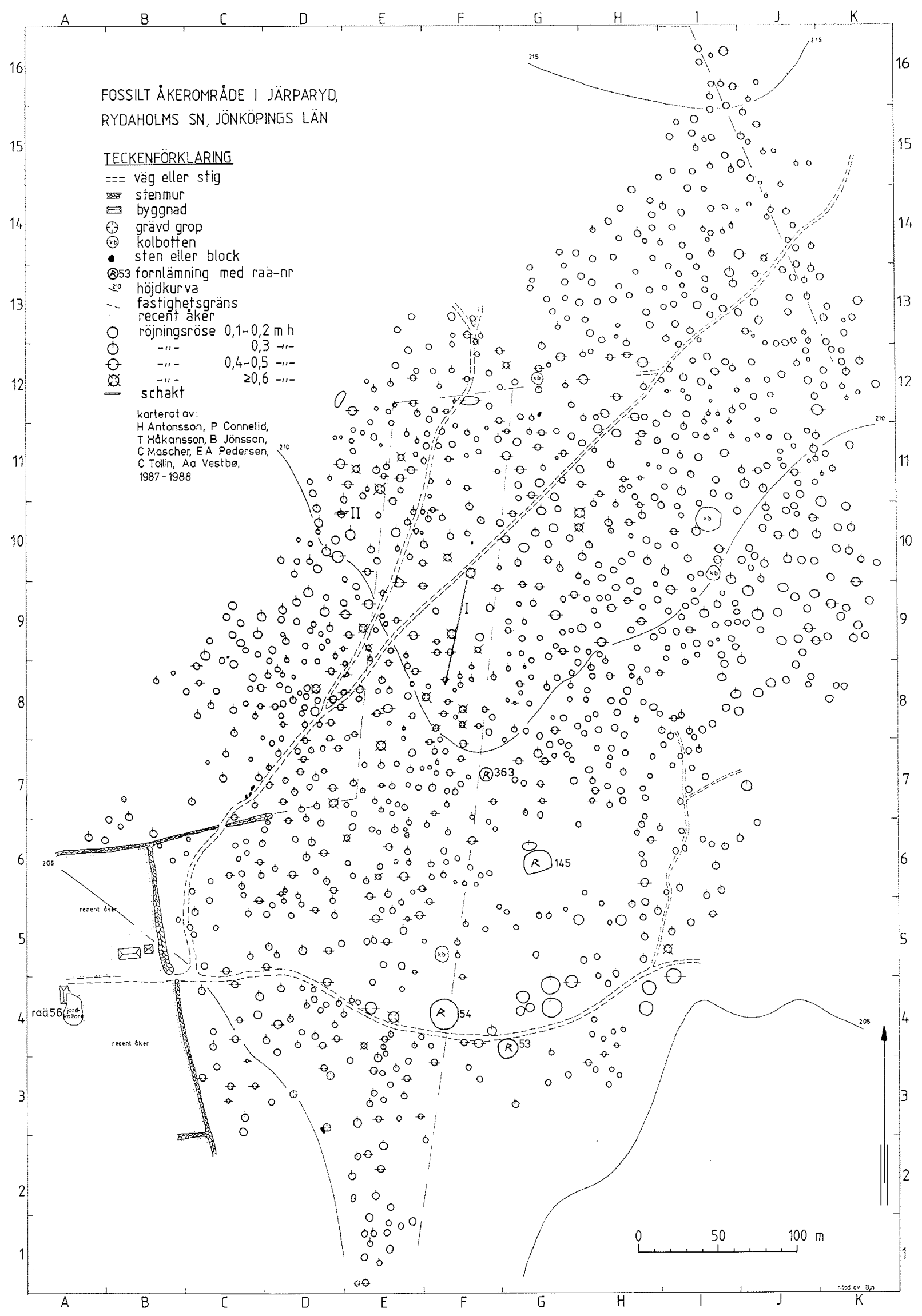

Fig. 10. Clearance-cairn field at Järparyd, parish of Rydaholm, Småland, Surveyed by Clas Tollin and Bo Jönsson (Tollin 1989). 
regular land division (Gren 1989; Norman 1989; Tollin 1989).

These cairn fields'are located in woodlands on the outlying lands of medieval and later settlements. Bronze Age and Early Iron Age burial cairns can often be found centrally located within them. Some of the cairn fields are so small that it is reasonable to assume that they were tilled by a single household, while others, to judge from the area that they cover (up to some 200 hectares), must have been used by a community of agriculturalists. In some areas, such cairns can be found on almost all dry land that has not been in recent cultivation. The map (Fig. 10) shows one of the localities which has been surveyed by Clas Tollin and Bo Jönsson.

The cairn fields have the following traits in common with the localities discussed above. They are usually situated in the same type of terrain - on the crests of gentle elevations above the marine limit. Furthermore, they are situated in the same context of burial monuments. A rough dating thus places the two types of fossil fields in the same time period. The techniques of tilling seem also to have been the same, and this points to a semi-permanent agriculture without any traction implements. Within the regularly divided fields can be found clearance cairns of the same type as those in the cairn fields.

I am thus arguing that these two types of agrarian landscapes represent the same type of farming system from a technological and ecological point of view. The main difference between the cairn fields and the regular strip fields thus lies in the way property rights are expressed on the ground.

These two types of landscapes may thus represent chronological stages in a development, but one should also bear in mind the possibility that they may have existed in parallel in nearby areas. In either case, the fact that we today find them in roughly the same areas and chronological contexts raises questions about the dichotomy. Above, I have ruled out farming techniques and differences in the natural environment as the causative factor in the dichotomy.

\section{RECENT PARALLELS}

Some works on nineteenth- and early twentiethcentury agrarian organisation seem to shed some light on this dichotomy. Farming in strips has in the last two centuries been documented in eastern Europe (Stahl 1980) and northern and eastern Africa (Bessis et al. 1956; Shipton 1984; Håkansson 1988). In neither of these cases is the form of the strips connected with the implement used and in most cases some kind of itinerant agriculture was practised.

The social historian H. H. Stahl led interdisciplinary village investigations in Romania between the wars, using an ethnological and retrogressive historical approach (Stahl 1939, 1959-65). These voluminous works give marvellously detailed accounts of farming practices, patterns of inheritance and property rights in different types of traditional villages in Romania. A synthesis in English was published in 1980.

On the one hand, Stahl investigated villages where the individually cultivated land was not demarcated but where land rights were based on (1) the membership of a kinship group and (2) on the work done in clearing semi-permanent, arable fields. In other villages that he studied, rights to land were of another character. Land was divided among the families in strips. A village was said to 'walk on' a certain number of ancestors, who were considered to be the sons of an eponymous founder of the village, and the rights of each household were defined according to a real or perceived gencalogy, which all agreed upon. According to Stahl, the villages of the later type were a direct development from the more primitive ones.

Strip fields related to kinship organisation have also been documented from northern Africa. Especially striking is the ownership pattern reproduced by Bessis from the highland zone in Tunisia (Fig. 11). This shows the situation at a stage at which a nomad clan had recently become sedentary (Bessis et, al. 1956).

In a paper with the striking title of 'Strips and patches', Parker Shipton has summarised studies of land tenure in eastern Africa. He shows how the land-holding systems and the political systems are closely related. On the one hand, there are localitybased systems in which rights to land are based on group membership and in which full cultivation rights are granted to all members. Inherited holdings were not subdivided. Fields were laid out in patches and their placement had little or nothing to do with the genealogical positions of their holders. On the other hand, there are descent-based systems in which the membership of the political units is determined by real or fictive kinship. Inherited holdings were subdivided amongst all sons. In these systems, the land is laid out in parallel strips extending from homesteads, and their placement reflects the genealogical positions of their holders (Shipton 1984, p. 616).

Taken together this evidence is, first of all, a

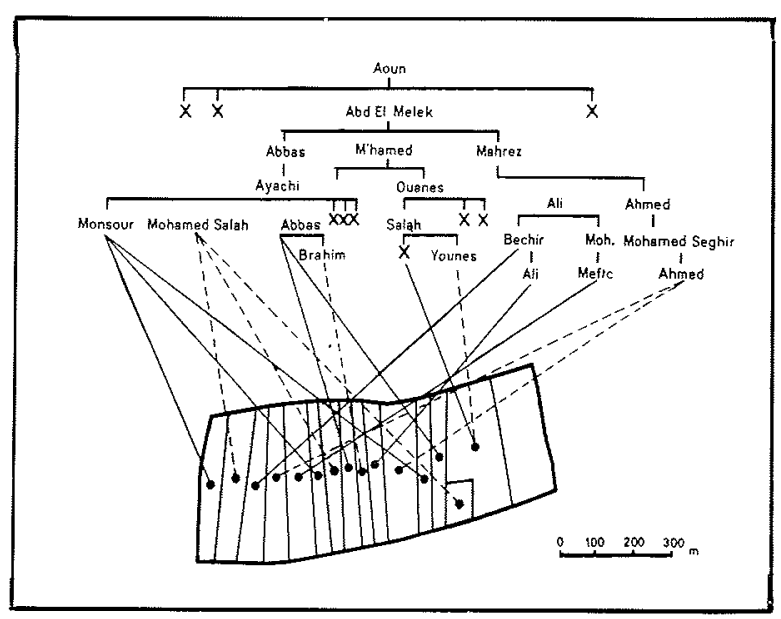

Fig. 11. Emergence of broad parcels through land division of a clan, SW. of Sidi Bou Zed, Tunisia. (From Bessis et al. 1956). 
reminder of the fact that farming in strips can be documented in quite different social and ecological contexts than those in medieval Western Europe. Secondly, this shows that the strip pattern is often found in contexts where land rights were based on kinship. In the words of Shipton, the strip fields provided an orderly pattern for lineage control of land' (Shipton 1984, p. 618).

These ethnological parallels support the idea of share-holding as the origin of subdivided fields. The communities that produced clearance-cairn fields may also have worked on the basis of some kind of shares - equal or unequal proportions of the whole - most probably based on the real or perceived genealogy of the community. In the first stage, these shares were not expressed in physical land delimitations but maybe in other parts of daily economic and spiritual life. Under certain circumstances there develops a need to recalculate and express the shares on the ground.

\section{METROLOGICAL ANALYSIS}

The discussion above has served to open up the possibility that arable land in Sweden during the Iron Age may have been divided on the basis of shares, which, previous to the parcelling, had been expressed in other forms. Two possible developments from an originally egalitarian shareholding can be considered.

(a) The land division may have taken place at a stage at which all partakers in the community still held equal rights to land. This would, in the primary stage, result in a frame planning with large blocks of land equal in size. Subsequently, the frame parcels may have been divided as an effect of partible inheritance. After some generations, this would result in a complicated field pattern, in which, however, it would still be possible to identify the original frame parcels.

(b) A more complicated case would be the situation in which the shares had already become unequal, though this was not yet expressed in the actual piece of land. The shares may have been calculated on the basis of genealogy. If the genealogy is known and undisputed, the fact that you count yourself as the son (or daughter) of $X$, who is the son of the 'village founder', is in fact a mathematical expression of a share, which, depending on the number of heirs in each generation, could be between, say, a quarter or a 25 th of the whole community. This measure may also have been expressed as numbers of some other type of utility (rights of grazing for a number of animals, rights to a certain number of beehives) or may, of course, have been transformed into a village measure expressed in lengths comparable to the later-used term byamål (village measure).

In both cases, the process behind the parcelling would have left definite signs of regularity in the field system. In case (a) it becomes a question of identifying the frame parcels and, secondly,

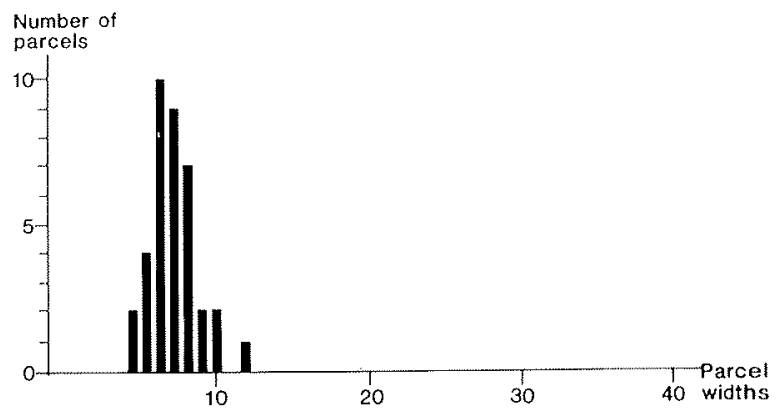

Fig. 12. Parcel widths on Krabbetorp, a deserted fourteenthcentury farm in Bohuslän.

identifying the smaller parcels as fractions of the whole. The field pattern documented at Mannstad (Fig. 6) agrees well with such a process. But in the other localities the planning ideas are less transparent. At a first glance at the maps, the breadths seem to be haphazardly distributed; no simple interpretation of the layout can be made by ocular inspection of the map. The question is now whether the breadths of the parcels in the two other localities (Iäggared and Gisslarp) can be interpreted as having been caused by either process (a) above, where the frame parcels have been hidden by later development, or whether they may be the result of the second alternative $(b)$. In the latter case, it is not necessary that the genealogy is directly expressed on the ground. The calculated shares may have been laid out in the field with the help of a lottery. In both cases, some kind of measuring rod or rope must have been used in the laying out. The observed breadths should then conform to multiples of this module.

The aim of a metrological analysis is to detect underlying modules in a distribution of breadths, widths or other measures from fields, buildings or other man-made structures, in which we may suspect that regular measures were used in the layout. A graph of the distribution of the breadths of fields may give a first impression of the possibility that underlying modules may explain the breadths. The problem is illustrated in Fig. 12, which is based on the breadths of 37 parcels of ridge and furrow on a deserted, medieval, single farm in Bohuslän, Sweden. As can be seen from the figure, this is a normal distribution around a mode of about six metres. Since this is a single farm, we have no reason to assume that the breadths of strips should be in accordance with some village measure. In this case, it is more probable that the breadths represent variations around a normal breadth for a working parcel tilled with the western-Swedish type of traditional plough.

The corresponding diagram for the Låggared locality presents another aspect (Fig. 13). No single mode can be pointed out. This preliminary analysis supports the hypothesis that the layout is based on a module.

Metrological analysis of early field measurement has been developed by David Hannerberg. In 1955 , 
he published an overview of early measurement units used in buildings and fields in Scandinavia. On the basis of work by Broadbent (1955), he also further developed the statistical analysis on a number of empirical distributions of field breadths (Hannerberg 1967). Following the formulas in Broadbent, it is possible to estimate the module and to demonstrate that the data are not more likely to be a random sample from some other type of distribution: unimodal (cf. Fig. 12) or rectangular (with randomly spaced breadths). Independently of the work of Broadbent and Hannerberg, Nielsen and Nielsen have written a data program for the same type of problem (Nielsen \& Nielsen 1978). A closer description of the method and test values can be found in their works.

The values used in the test have to be measured in the field on the basis of an accurate map. Two or three measurements have been taken on each parcel. All measurements are given in metres to one decimal point. If the parcel has been judged to be basically rectangular, the mean of these values has been used in the further analysis. Trapezoid or triangular parcels have not been used in the analysis.

The analysis is carried out by a number of successive divisions. A test value $\mathrm{s}^{2} / \mathrm{d}^{2}$ is plotted against a series of the hypothetical modules, which can be chosen at different intervals and with different increments. The minima on this curve correspond to modules with different levels of significance. For the test of significance, the tables in Broadbent have been used. The tests have been made in steps with a graphical analysis as the first step. As a second step the minima indicated by the graphical analysis have been analysed with a smaller increment in order to determine a module value in metres with two decimal points. The tests have been performed with the help of BASIC programs written by the author on the basis of the formulas given in Hannerberg 1967. For comparison, the program written by Nielsen and Nielsen has also been tested on the material with basically the same results. The resulting modules have been compared with the early Scandinavian units of measurement in Hannerberg (1955). Further examples of the application to early fields of this method can be found in Lindquist (1968, 1974) and Sporrong (1971).

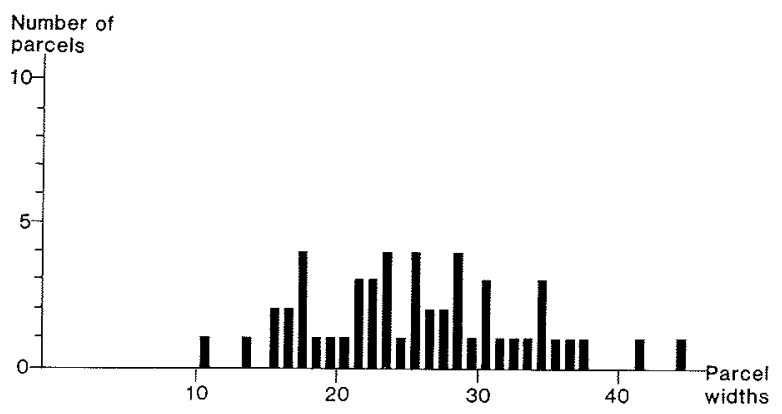

Fig. 13. Parcel widths in Läggared.

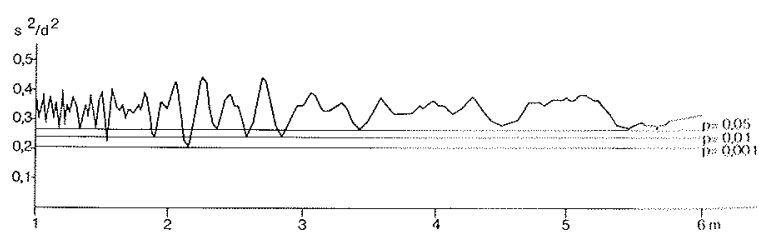

Fig. 14. Graph of values of $\mathrm{s}^{2} / \mathrm{d}^{2}$ for every second centinetre between 1 and 6 metres. Läggared

\section{LÄGGARED}

In the Läggared locality, forty-nine parcels have been used in the module analysis. As can be seen already from the diagram (Fig. 13) the values have a tendency to concentrate around certain values. In Fig. 14 , the test value $s^{2} / \mathrm{d}^{2}$ is plotted against tested modules between 1 and 5 metres with an increment of 2 centimetres. The lower the test value, the better is the fit as a module in the series of parcel breadths. In the diagram, a module between 2.1 and 2.2 metres shows the lowest test value. A closer search with an interval of 0.001 metres defines this minimum as 2.134 (close to 99.9 per cent significance). There are thus good reasons to interpret this value as the module used in the laying out of the fields $(M)$.

Values under 1 metre should be used with caution, since every distribution of breadths produces many short, possible modules ( $c$. Hannerberg 1967), but in this case one of the lower values has an extremely high significance. The module 0.43 metre has a test value of 0.2000 , which in this case is well above the 99.9 per cent level. It is easy to show that 0.43 is about one-fifth of the module $M$. It is thus highly probable that they both reflect the same basic measure. 0.43 metres is a value of the magnitude of an ell. Since ells of this size used to be based on one and a half feet the corresponding foot would be around 0.287 metre ( $c f$. Hannerberg 1955). Following Hannerberg's connotations the metrological solution to the parcel widths could be written like this:

$\mathrm{M}=5 E$ ('measuring rod')
$E=1.5 F$
$F=0.285$ metres

This foot measure is, of course, close to the Roman foot of 29.6 centimetres, but, according to Hannerberg, different, shorter, foot measures around 28.5 centimetres have been used so widely and for such a long time that they should be considered as an independent measure in Scandinavia ('Germanic foot', Hannerberg 1955, p. 10). Hannerberg refers to a house foundation in Denmark dating from the second century A.D., which has been constructed on the basis of an ell of 28.3 centimetres.

When the whole field system is expressed on the map in modules $(M=2.13)$, no apparent pattern of subdivisions covering the whole area shows up. Thus, the overall idea behind the layout still cannot 
TAIBLE 1. STRIP WIDTHS AT IÄGGARED

\begin{tabular}{|c|c|c|c|}
\hline $\begin{array}{c}\text { Sirip } \\
\text { width } \\
\text { (metres) }\end{array}$ & $\begin{array}{c}\text { No. of } M \\
(2.13 \text { metres })\end{array}$ & $\begin{array}{c}\text { Possible frame } \\
\text { modules } \\
\text { (in meters) }\end{array}$ & $\begin{array}{c}\text { No. of } M \\
\text { (2.13 metres) }\end{array}$ \\
\hline 30.8 & 14 & \multirow[t]{2}{*}{45.9} & \\
\hline 15.1 & 7 & & \\
\hline & & \multirow{4}{*}{45.0} & 42 \\
\hline 26.3 & 12 & & \\
\hline 18.7 & 9 & & \\
\hline 34.5 & 16 & & \multirow{4}{*}{42} \\
\hline 17.1 & 8 & \multirow[t]{3}{*}{89.8} & \\
\hline 16.7 & 8 & & \\
\hline 21.5 & 10 & & \\
\hline
\end{tabular}

be directly read from the map. In parts of the field system, it is, however, possible to go further. Table 1 shows an apparent subdivision of eight strips close to Lillegården. It is possible to interpret this part of the field as consisting of two original frame parcels with a breadth of $42 M$, which have been subsequently divided (Table 1 ).

\section{GISSLARP}

In the Gisslarp locality, the middle and northern areas have been included in the metrological analysis. For unknown reasons the southernmost parcels have irregular widths. Forty-three values are included in the analysis. As can be seen from the diagram (Fig. 15), there are two minima which are significant at the 95.per cent level. A closer search defines these as 1.13 (above the 99 per cent level) and 5.24 (significant at the 95 per cent level). The values could be interpreted as $4 F(0.2825)=1.13$ or $18 F(0.291)=5.24$. The first value is close to the 'Germanic foot' of the same magnitude as in Läggared, while the second value is close to a Roman foot, which has previously been found in Swedish fields dating from the Roman Iron Age (Lindquist 1968). One should, however, be careful about drawing chronological conclusions from this, since the $M=5.24$ could also be interpreted as 9 Swedish ells of 59 centimetres, a measure which was in use from the seventeenth century onwards. A further analysis of the fitness of the different values showed, however, that a large part of the central area had a very nice sequence of measures when it was interpreted with the last module 5.24 (see Table 2).

It should also be remarked that the first seven strips together form $33 M$ and the last twelve strips together form $32 \mathrm{M}$. These two groups may be remnants of two primary, very wide strips some 170 metres or $576 \mathrm{~F}$ in width.

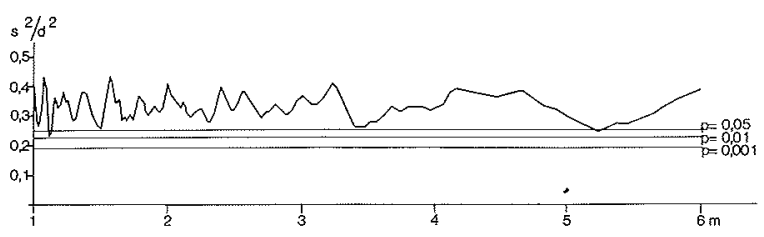

Fig. 15. Graph of values of $s^{2} / d^{2}$ for every second centimetre berween 1 and 6 metres. Forty-three parcels in the northern part of Gisslarp.

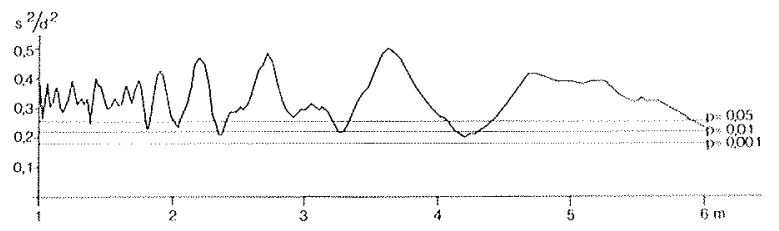

Fig. 16. Graph of values of $s^{2 /} \mathrm{d}^{2}$ for every second centimere between 1 and 6 metres. Norra Unnaryd.

NORRA UNNARYD

In Norra Unnaryd, a similar locality has been mapped (Vestbö 1989). Thirty-five parcel widths have been available for a metrological analysis (Fig. 16). The absolute minimum of the test value occurs at $M=4.20$ (significant at the 99 per cent level). Of the ells and feet discussed by Hannerberg, this value fits best into a 'Germanic' measure of 28.5 centimetres, although the one found here is somewhat shorter. The rod or rope may have been based on $15 F$ of 28 centimetres.

\section{MÂNSTAD}

The Månstad locality has already been discussed above and a preliminary analysis of the plan was discussed. The parcel widths in Månstad have also been analysed formally by the metrological method, but with no significant results, except the obvious one that 10.5 and 21.1 metres (quarters and halves of the general widths of around 42 metres) are significant modules in the southern 'furlong'. This can be interpreted as meaning that the frame parcels around 42 metres were planned as $144 F(0.293$ metre), which again is close to the Roman foot ( $c f$. Gisslarp.

TABLE 2. STRIPS IN GISSLARP (PART OF)

\begin{tabular}{cccc}
\hline $\begin{array}{c}\text { Strip } \\
\text { width }(\mathrm{m})\end{array}$ & $\begin{array}{c}\text { No. of } M \\
(5.24 \mathrm{~m})\end{array}$ & $\begin{array}{c}\text { Possible frame } \\
\text { modules }(\mathrm{m})\end{array}$ & $\begin{array}{c}\text { No. of } M \\
(5.24 \mathrm{~m})\end{array}$ \\
\hline 27.1 & 5 & 64.2 & 12 \\
37.1 & 7 & & \\
16.5 & 3 & 67.0 & 13 \\
15.5 & 3 & 42.6 & 8 \\
35 & 7 & & \\
15 & 3 & 40.4 & \\
27.6 & 5 & & 8 \\
21 & 4 & & \\
19.4 & 4 & 43.5 & \\
22.7 & 4 & & \\
10.5 & 2 & & \\
10.3 & 2 & 41.5 & \\
21 & 4 & & \\
10.6 & 2 & & \\
9.9 & 2 & & \\
10.6 & 2 & & \\
11.6 & 2 & & \\
11 & 2 & & \\
10.3 & 2 & & \\
\hline
\end{tabular}




\section{METROLOGICAL ANALYSIS: CONCLUSIONS}

It has thus been possible to show that the strip widths in the four discussed localities are not haphazardly distributed. All the localities show a distribution of breadths which conforms to the quantum hypothesis. From this, we may conclude that the strip fields must have been laid out with the help of some kind of measuring technique. The regularity which the statistical analysis points to would be difficult to explain otherwise. The actual measures used in the laying out may have been based on a common measure of the magnitude of a Roman foot and/or a shorter 'Germanic foot', which, according to David Hannerberg, has a long tradition in the Scandinavian countries. Both these measures thus fall well into the chronological framework indicated by other dates from the strip fields.

When it comes to understanding the principles behind the layout, only partial answers are possible at this stage. At Månstad, Läggared and Gisslarp, it has been possible to identify frame parcels in one part of the field system, but in a large part of the field systems we can say only that modules have been used - not how and why. A development according to $(b)$ above, where strips have been distributed on the basis of a lottery, is a possibility. One common trait at both Läggared and Gisslarp is that frame parcels and simple sequences of breadths have been identified in the central parts of the field system, while the peripheral parts are more difficult to interpret. For the further analysis of the processes behind the layout, we are obliged to resort to detailed investigations in the field.

\section{CONCLUSIONS}

The findings of strip fields in an Iron Age context in Sweden have challenged previous ideas on the development of field systems in the country. Strip fields can obviously not be seen as a purely medieval phenomenon connected with the development of the two- and three-field systems. In this paper, I have tried to show that the regular, often rather wide strips have been parcels of land-holdings rather than working parcels. It seems highly probable that they represent the intermixture of property within a farming community. On the basis of evidence from Romania, Tunisia and eastern Africa, it can be argued that regular strip fields have been a common way of expressing land rights within a society based on kinship. This may well have been valid also for Early Iron Age Scandinavia. The metrological analysis carried out in this paper gives support to the idea that the fields may have been developed from wide frame parcels which were subsequently subdivided with the help of a measuring technique.

The stylized facts of the development in the investigated area can be described as having occurred in three phases:
PHASE A

Some time in the Bronze Age or the Early Iron Age - say between 1000 B.C. and the birth of Christ farming was carried out on a semi-permanent basis by agrarian communities. Share-holding may have been part of the community's organisation, but was not expressed on the ground. In areas where property relations were not further developed before the contraction of settlement in the middle of the first millennium A.D., the most distinct traces of this semi-permanent phase consist of large areas of clearance cairns.

PHASE B

Social development within these communities brought with it the need to express the shares on the ground, which in its initial phase gave rise to wide, regular strips. These fields were later gradually infilled with more stable working plots and also subdivided, due to partible inheritance. This process gave rise to the strip fields discussed in this paper.

\section{PHASE C}

After a contraction of settlement in the middle first millennium A.D., the land use was focused more on the individual farmsteads. Arable was held in severalty and the old strips now functioned as working plots within larger blocks of privately owned arable. On the periphery of the arable, subdivided fields gradually re-emerged as a result of piecemeal colonisation of the formerly common meadowland.

Going back to the original question of the origin of the strip fields depicted on the seventeenthcentury maps, we thus have to consider a chronological and social context quite different from the medieval situation. In this particular case, the strip fields had their origin in prehistoric land divisions. The same forms have had different functions over time and the origin of the forms cannot be interpreted on the basis of the maps alone. Expressed in the 'traditional terms' of the open-field debate, the seventeenth-century pattern is primarily the result of a physical structure developed in prehistory on the basis of share-holding and partible inheritance. Once the strips were 'painted' on the ground, the land took on another character and the geometrical pattern of the fields must have influenced the views of all subsequent farmers on land division and ownership. In the late medieval landscape, the prehistoric strips became working parcels within compact ownership blocks close to the settlement, but they also provided an already existing, regular pattern for piecemeal colonisation of the grasslands surrounding the core arable. Once imprinted on the landscape, the same forms have a tendency to reappear in partly or wholly changed functions. 
This study was financed by the Swedish Council for Research in the Humanities and Social Sciences. Financial contributions have also been received from the County Museum of Älvsborg and the Lillemor and Hans W:son Ahlmans Foundation for Geographical Research. Per-Eric Ullberg Ornell introduced me to the field area and also took part in the fieldwork, together with numerous students, all of whom are heartily thanked, especially Catharina Mascher and Aadel Vestbö. The drawings were made by Katarina Strömdahl and Catharina Mascher. A considerable amount of moral and practical support was given by Kurt Aronsson in Gisslarp, Månstad
Snickeri- och Bobinfabrik, Månstad hembygdsförening, Gösta Larsson and Liss Larsson Månstad, and MajBritt Svenningson and Nanna Larsson at Nilsagåden in Läggared. An early version of the paper was read at the Permanent European Conference for the Study of Rural Landscape in Stockholm 1987 and at a seminar at the Department of Archaeology and Prehistory in Sheffield in November 1988. I am grateful to Robert A. Dodgshon and Andrew Fleming for literature references and valuable comments on ideas in the paper. Neil Tomkinsson, B.A., revised the English text.

FOOTNOTE

The Swedish Iron Age extended from about 500 B.C. to A.D. 1050.

BIBLIOGRAPHY

Bessis, A., Marthelot, P., de Momrety, H., \& Pauphilet, D., 1956. Le Territoire des Ouled Sidi Ali ben Aoun, Presses Universitaires de France (Paris).

Broadbent, S. R., 1955. 'Quantum hypotheses', Biometrica, 42, pp. 45-57.

Brongers, J. A., 1976. Air Photograpby and Celtic Field Research in the Netberlands, Nederlandse Oudheden 6, (Amersfoort).

Carlsson, D., 1979. Kulturlandskapets utveckling på Gotland, (Engl summary) (Visby).

Dahlman, C., 1980. The Open Field System and Beyond. A Property' Rights Analysis of an Economic Institution (Cambridge)

Dodgshon, R., 1980. The Origin of British Field Systems. An Interpretation (New York).

Erixon, S., 1960. Slenska byar utan systematisk reglering I-II (Stockholm).

Fenoaltea, S., 1988. 'Transaction costs, Whig history, and the common fields', Politics and Society, 16, pp. 171-240.

Fleming, A, 1987. 'Coaxial field systems: some questions of time and space', Antiquity, 61, pp. 188-202.

Fowler, P. J., 1983. The Faming of Prebistoric Britain (Cambridge).

Frandsen, K-E., 1989. 'The field systems of southern Scandinavia in the 17 th century: a comparative analysis', Geografiska Annaler, Ser B., 70B, pp. 117-22.

Gren, L. 1989. 'Det småländska höglandets röjningsröseområden' (Eng. summary) in Arkeologi i Sverige 1986. RÄ̈ (Central Office of National Antiquities) $1988: 2$ (Stockholm), pp. 73-96.

Göransson, S., 1985. 'De regelbundna strukturerna i östsveriges bebyggelsegeografi', Kulturgeografiska perspektiv, Geografiska Regionstudier $\mathrm{Nr}$ 15, Uppsala Universitet, pp. $65-82$.

Hannerberg, D., 1955. Die Älteren Skandinavischen Ackermasse, Lund Studies in Geography No. 12, ser B.

Hannerberg, D., 1967. Modulbestämningar, Forskningsprojektet Administrativa Rumsliga System, Meddelande 2. (Dept Human Geogr, Univ Stockholm).

Hannerberg, D., 1976. 'Models of medieval and pre-medieval territorial organisation', J Hist Geogr, 2, 1976, pp. 21-34.

Hatt, G., 1939. The Ounership of Cultivated Land, Det Kongelige Danske Videnskabers Selskab, Historisk-filologiske Meddelelser, XXVI, 6 .

Håkansson, T., 1988. Bridewealth, Women and Land. Social Change among the Gusii of Kenya, Uppsala Studies in Cultural Anthropology 10. Acta Universitatis Upsaliensis (Uppsala).

Klang, L., 1980. 'Sävsjö och Granhult i Uppvidinge härad - exempel pả fossila kulturlandskap', Kronobergsboken 1979-80, pp. 1-33.

Lindgren, G., 1939. Falbygden ocb dess nämaste omgibning tid 1600-talets mitt. Geographica Nr 6, (Uppsala)

Lindquist, S. -O., 1968. Det Förbistoriska Kulturlandskapet $i$ Östra Östergölland, Acta Universitatis Stockholmiensis, Studies in North-European Archaeology 2.

Lindquist, S. -O., 1974. "The development of the agrarian landscape on Gotland during the Early Iron Age', Norwegian Archaeol Rel, 7, pp. 6-32.

Lindquist, S. -O., 1976. 'Fossilt kulturlandskap som agrarhistorisk källa', Västergötlands fomminnesförenings tidskrift 1975-76, pp. 119-64.

Mascher, C. 1988. Odlingslandskapets urveckling under förhistorisk tid i Läggared och Veka, Västergötland. Mimeo. Dept Human Geogr, Univ Stockholm.

McCloskey, D. N., 1976. 'The persistence of English common fields, in European Peasants and Their Markets ed. Parker \& Jones (Princeton).

Nielsen, H. \& Nielsen, K. 1978. Module search by means of a computer, in New Directions in Scandinavian Archaeology, ed. K. Kristiansen \& C. Paludan-Müller, (Copenhagen), pp. $23-45$.

Norman, P., 1989. 'Röjningsrösen och förhistoriska gravar', (Engl. summary). Arkeologi $i$ Sverige 1986. RAÄ (Central Office of National Antiquities), 1988:2. (Stockholm), pp. 97-110

Shipton, P. M., 1984. 'Strips and patches', Man, pp. 616-20

Sporrong, U., \& Widgren, M., 1986. Ägande och disposition av mark som förklaringsfaktorer till kulturlandskapets urveckling. Mimeo. Dept Human Geogr, Univ Stockholm.

Sporrong, U., 1971. Kolonisation, bebyggelseutueckling och administration, Stockholms Universitet, Medd. B 29.

Sporrong, U., 1985. Mälarbygd. Agrar bebyggelse ocb odling urett bistorisk-geografiskt perspektiv (Stockholm).

Sporrong, U., 1988. 'Om storskiftet och det föregående äldre tegskiftet i Öster- och Västerdalarna', Bebyggelsebistorisk Tidskrift, nr 13, 1987.

Stahl, H. H., 1980. Traditional Romanian Village Communities (Cambridge).

Stahl, H. H., 1939. Nerej - un Village d'une Région Archaïque, Institut de science sociales de Roumanie (Bucharest).

Stahl H. H., 1959-65. Contributii la Studiul Satelor Devàlmase Rominesti (Bucarest).

Tollin, C., 1987. 'Colonisation and settlement in southern Sweden', in The Medieval and Early' Modern Rural Landscape, ed. H.-J. Nitz, Dept Geogr, Univ Göttingen. 
Tollin, C., 1989. 'Röjningsrösen i södra Sverige' (Engl. summary) Arkeologi $i$ Sterige 1986. RÄA (Central office of National Antiquities) 1988:2. Stockholm. pp. 53-72.

Vestbö, A, 1988. Fossil åkermark och kulturlandskapsutveckling i Gisslarp, Västergötland. Mimeo. Dept Human Geogr, Univ Stockholm.

Vestbö, A, 1989. Unpubl rep on investigations in Norra Unnaryd. County Museum of Jönköping.

Welinder, S., 1975. Prebistoric Agriculture in Eastem Middle Sweden. Acta Archaeologica Lundensia, Series in 80 Minore No. 4
Widgren, M., 1983. Settement and Faming Systems in the Farly' Iron Age, Stockholm Stud in Human Geogr 3

Widgren, M., 1987. 'Regelbundna ăkersystem frän aldre jänulder' Västgöta-Dal 1987, pp. 176-202.

Widgren, M., 1989. 'Geographical approaches to fietd systems ...' in Approaches to Swedish Prebistory' ed. T. B. Larsson \& 11. Lundmark, Br Archaeol Rep, Int Ser, 500

Windelhed, B., 1984. "Celtic fields" and other prehistoric landscapes, in Settlement and Economy in later Scandinavian Prebistory, ed. K. Kristiansen, Br Archaeol Rep, Int Ser 211.

The Society is grateful to the Swedish Council for Research in the Humanities and Social Sciences for a grant towards the cost of publishing this paper. 